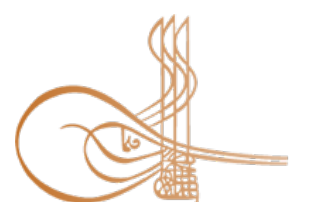

www.turkishstudies.net/economy
Turkish Studies - Economics, Finance, Politics

eISSN: 2667-5625

Research Article / Araștırma Makalesi

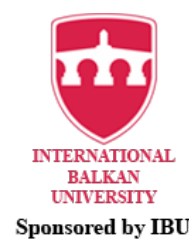

Sponsored by IBU

\title{
Lojistik Sektörü İş Gücü Profilinin Değerlendirilmesi: Karaman İli Örneği
}

\author{
Evaluation of Labor Profile of Logistics Sector: Sample of Karaman
}

\author{
Nursel Sağdıç* - Ahmet Alper Sayın**
}

\begin{abstract}
Cultural life developed under the influence of nomadic life, experiences gained through historical trade routes, the Peoples' Migration based on intensive human migration and the strategy of land-driven ships that took place in the conquest of Istanbul that closed an age are indicative of the fact that logistics has always existed in Turkish history. Recently, the more heard and perceived as a new concept logistics is actually as old as human history. The construction of the Egyptian pyramids as a primitive logistics, the conquest of Istanbul as a successful and strategic logistics, the Sarıkamış event as a failed logistics in the military field, the deployment of the Red Crescent during a natural disaster as a non-profit social logistics, the exchange of products from Hepsiburada to the customer logistics in the modern sense. Regardless of how logistics is defined, it is an important and complicated concept that cannot be dispensed with today as old as human history. In every sense developing world; speed, technology and information are essential concepts. One of the sectors that contributed to and supported this change in the new world is undoubtedly the logistics sector. It is possible to talk about logistics in the supply, production and consumption of every product we see around us. Manpower is the most important actor of this sector, which is so important and whose value increases with the increasing momentum. For an efficient, fast and error-free logistics activities, the existence of a wisely selected employment structure shaped according to the structure of talent, education and experience is required. The existence of this workforce is important in making a difference and strengthening economically. In this study, the importance of logistics and explained the situation in Turkey, labor is a critical factor for logistics concept will be evaluated and reviewed in a special Karaman Province.
\end{abstract}

Structured Abstract: Introduction With globalization in today's world; Changes and developments in informatics, technology, management and economic life increase the importance of qualified manpower with the effect of tough competition. Over time, there are significant integrations and divergences between main sectors. In the last half of the century, the increasing migration from the village to the city center, fragmented agricultural lands, the spread of educational opportunities and the rapid advancement of technology brought

\footnotetext{
* Yüksek Lisans Öğrencisi Karamanoğlu Mehmetbey Üniversitesi, Sosyal Bilimler Enstitüsü, Uluslararası Ticaret ve Lojistik Yönetimi ABD

Graduate Student, Karamanoglu Mehmetbey University, Social Sciences Institute, International Trade and Logistics Management MBA

ORCID 0000-0002-6776-3681

nurselsagdic@kmu.edu.tr

${ }^{* *}$ Dr. Öğr. Üyesi, Karamanoğlu Mehmetbey Üniversitesi, Uygulamalı Bilimler Yüksekokulu, Uluslararası Ticaret ve Lojistik Yönetimi Bölümü

Asst. Prof. Dr, Karamanoglu Mehmetbey University, School of Applied Sciences, International Tradeand Logistics Management

ORCID0000-0002-2086-6763

ahmetalpersayin@kmu.edu.tr

Cite as/ Atıf: Sağdıç, N \& Sayın, A. A. (2020). Lojistik sektörü iş gücü profilinin değerlendirilmesi: Karaman ili örneği.

Turkish Studies - Economy, 15(3), 1579-1606. https://dx.doi.org/10.47644/TurkishStudies.41457

Received/Geliș: 22 January/Ocak 2020

Accepted/Kabul: 20 September/Eylül 2020

Checked by plagiarism software

Copyright (C) INTAC LTD, Turkey 
about employment shifts from agriculture to the services sector. Due to its geographical location, Turkey is a developing rapidly in the logistics industry, labor, logistics and technology are increasing the importance of well-trained labor force due to intensive sector.

In this study, the general logistics workforce information will be given and the profile of the logistics sector employees in Karaman province will be evaluated on the criteria of gender, age, education, marital status, working year and working time. By creating a conceptual framework, meetings were held with logistics company officials in the province, and a general logistics workforce profile was evaluated.

\section{Purpose}

With this study, it is aimed to evaluate the profile of Karaman province logistics sector employees in the light of general logistics activities and logistics workforce profile data. In the study conducted with companies engaged in logistics activities, it is aimed to determine whether the employees are similar to the general logistics sector employee profile and what the strengths and weaknesses of the profile are by evaluating them on criteria such as gender, education, marital status and experience.

\section{Importance of the Study}

In today's world, the logistics sector, which is increasingly important and in contact with every sector; Undoubtedly, one of the most important factors in being competitive in terms of speed, quality, efficiency and profit is the human factor. A well-equipped workforce should be evaluated well with its added value creating feature in the logistics sector as in every sector. This study is important as it is aimed to utilize the workforce at the highest level by determining the current situation, evaluating its strengths and weaknesses, by evaluating the logistics sector in terms of the workforce of the province of Karaman. It is a well-known fact that the right employment in the logistics sector will provide economic benefits.

\section{Method}

In the study, data were obtained by using one-to-one interviews with the human resources department of 6 companies with logistics activities. Studies have been conducted on both the total employee profile and the employee profile in logistics activities in food-based production companies.

\section{Conclusion and Recommendations}

In the profile study for the workforce working in logistics activities in the province of Karaman, it can be said that the number of employees increases at the same rate as the company capacity and production volume increase. The number of blue-collar employees is higher, especially in companies engaged in production-based logistics. White-collar employees consist of experienced and well-educated employees with longer working hours in the company. They have a say in the process and can take initiative. This segment, which is more advantageous than blue collar in terms of salary, is more open to personal and professional development. They are proportionally less than blue-collar employees and all employees with higher education are in this group.

In the profile of employees in logistics activities in Karaman province: There is a high profile of married males between the ages of 18-25, primary-secondary school graduates, working less than 3 years in the workplace. These employees, who are preferred because they can be employed with low wages and can be easily sacrificed when production decreases, are seen as an advantage in reducing the labor cost, but they are insufficient in having a qualified workforce. They are mainly employed in unskilled jobs in the storage and packaging departments.

As a result of the evaluation of the logistics sector workforce profile, it can be said that there is an unqualified and inexperienced workforce for the province of Karaman. In this sector, which includes the elements of speed, quality and trust, in order to take a place in tough competition and to provide cost advantage; Well trained, equipped and stable employees are required. In this context, companies should focus on establishing their own logistics teams, employ well-trained personnel with the necessary training, and extend the time worked in the company with a fair wage policy. Company policies should be established to solve the qualified labor problem. Theoretical education should be supported with practical training, with an emphasis on education in general, the sector should be encouraged and distinguished. They should act jointly with professional associations to work towards establishing the logistics service standard. In addition to low labor cost, high productivity should also be considered. Firms should use human power in increasing their 
competitiveness and branding. They should integrate knowledge, technology and human subjects, and develop both employees and the company through continuous learning and development practices.

Considering the developed industry of the province and exports to more than 150 countries, the importance of stable employees should be noticed. It should be tried to provide experience and institutional belonging depending on stability. Long-term employment of the same employee should be aimed and tasks should be assigned in line with their abilities and should be supported by training.

Government policies should also support the logistics sector employees, and vocational high schools that include a logistics department should be established for unskilled employees in the sector to receive logistics training at secondary education level.

Keywords: Production and Operations Management, Logistics, Logistics Sector, Logistics Labor Force, Karaman

Öz: Göçebe hayatın etkisiyle gelişen kültürel yaşam, tarihi ticaret yollarıyla edinilmiş tecrübeler, yoğun insan göçü temeline dayanan Kavimler Göçü ve bir çağı kapatan İstanbul'un fethinde gerçekleşen gemilerin karadan yürütülmesindeki strateji, Türk tarihinde lojistiğin aslında her zaman var olduğunun göstergesidir. Son dönemde daha çok duyulan ve yeni bir kavram gibi algılanan lojistik aslında insanlık tarihi kadar eskidir. Mısır piramitlerinin inşası ilkel lojistik, İstanbul'un fethi başarılı ve stratejik lojistik, Sarıkamış olayı askeri alanda başarısız bir lojistik, Kızılay'ın doğal afet sırasında konuşlanması kâr amacı gütmeyen toplumsal bir lojistik, internet alışverişi ile Hepsiburada'dan alınan ürünün müşteriye ulaşması modern anlamda lojistik olarak örneklenebilmektedir. Lojistik nasıl tanımlanırsa tanımlansın insanlık tarihi kadar eski günümüzde vazgeçilemeyecek kadar önemli ve komplike bir kavramdır. Her anlamda gelişen dünyada; hız, teknoloji, enformasyon olmazsa olmaz kavramlar olarak karşımıza çıkmaktadır. Yeni dünyada bu değişime en fazla katkı sağlayan ve destekleyen sektörlerden biri kuşkusuz lojistik sektörüdür. Çevremizde gördüğümüz her ürünün temininde, üretiminde ve tüketilmesinde lojistikten bahsetmek mümkündür. Bu kadar önemli ve her geçen gün artan ivme ile değeri yükselen bu sektörün en önemli aktörü insan gücüdür. Etkin, hızlı ve hatasız bir lojistik faaliyetleri için akıllıca seçilmiş, yetenek, eğitim ve tecrübe yapısına göre şekillendirilmiş istihdam yapısının varlığı gereklidir. Bu işgücünün varlığı fark yaratmada ve ekonomik olarak güçlenmede önemlidir. $\mathrm{Bu}$ çalışmada lojistiğin önemi ve Türkiye'deki durumu açıklanarak, lojistik için kritik bir faktör olan işgücü kavramı Karaman İli özelinde değerlendirilerek yorumlanacaktır.

Anahtar Kelimeler: Üretim ve Operasyon Yönetimi, Lojistik, Lojistik Sektörü, Lojistik İşgücü, Karaman

\section{Giriş}

Mantık ve istatistik kelimelerinin birleşimi olarak da tarif edebilen lojistik kavramı tarihin her aşamasında olduğu gibi günümüzde de en etkin şekilde her alanda görülmektedir. Lojistik, iktisadi dünya düzeninde dolaylı ya da doğrudan her sektörle yakın ilişkilidir ve birbiri içine geçmiş durumdadır. Teknolojinin hızlı gelişimi, küreselleşmenin etkisiyle birbirine yakınlaşan kültürler, modern yaşamla birlikte yükselen hayat standardı ve beklentiler, elektronik ağlarla hızlanan ticari hayat lojistiği vazgeçilmez kılmaktadır.

Tüketilen ve sahip olunan her ürünün, her bileşeninde ve her sürecinde lojistik faaliyetlerden bahsetmek mümkündür. Gerek firma bazında gerek genel ticari büyüme içinde sektör olarak etkin ve karlı bir lojistikten bahsedebilmek için birçok olguyu bünyesinde barındırması gerekmektedir. Mekânsal yapı, teknoloji, bilgi ve donanım yanında belki de en önemlisi kaliteli ve istikrarlı işgücüne sahip olmasıdır. Hem teknolojinin, hem bilginin hem de emeğin bütünleşik ve eş zamanlı kullanıldığı lojistikte, uzmanlaşmış, nitelikli, gerekli donanımı bünyesinde bulunduran çalışanlara sahip olması gerektiği inkâr edilemez bir gerçektir ki bu olgu rekabet üstünlügünü de beraberinde getirmektedir. Bir dizi tümleşik faaliyetlerden (depolama, elleçleme, sipariş vb.) oluşan lojistik akıllıca oluşturulmuş istihdam yapısıyla firmaya marka ve imaj değeri katarken aynı zamanda ekonomik kazanç ve sektörel bazda da büyüme sağlamaktadır (Alamdarı, 2016: 3). Türkiye gibi genç ve 
dinamik nüfusun yoğun olduğu ülkelerde işgücü istihdamının en uygun şekilde yapılmas1 beklenmektedir.

İşücü sermayesi, firmaya özgü olması ve akıllıca istihdam edildiği ölçüde değerli ve taklidi en imkansız olması nedeniyle firma için en önemli kaynaklarından birini oluşturmaktadır (Hatch ve Dyer, 2004: 1172). Bir firmayı rakiplerine göre farklı kılan şeylerin firmanın kaynak ve yetenekleri olduğu yadsınamamaktadır (Colombo ve Grilli, 2005: 810).

Günümüz dünyasında küreselleşmeyle birlikte, bilişimde, teknolojide, yönetimde ve ekonomik hayatta yaşanan değişim ve gelişimler, zorlu rekabetin etkisiyle nitelikli insan gücünün önemini arttırmaktadır (Koban ve Keser 2013: 32-43). Zamanla ana sektörler arasında önemli bütünleşmeler ayrışmalar olduğu göze çarpmaktadır. Son yüzyılın yarısında giderek artan köyden şehir merkezine göç, parçalanan zirai araziler, eğitim olanaklarının yaygınlaşması ve teknolojinin hızla ilerlemesi tarımdan hizmetler sektörüne istihdam kaymalarını beraberinde getirmiştir. Bulunduğu coğrafi konum gereği Türkiye lojistik sektöründe hızla gelişmekte, lojistiğin emek ve teknoloji yoğun bir sektör olması nedeniyle iyi yetişmiş işgücünün önemi artmaktadır.

Bu çalışma ile genel lojistik işgücü bilgileri verilerek, Karaman ili lojistik sektörü çalışanları profili cinsiyet, yaş, eğitim, medeni durum, çalışma yılı ve çalışma süresi kriterleri üzerinden değerlendirilecektir. Kavramsal çerçeve oluşturularak, ilde lojistik firma yetkilileri ile görüşmeler yapılmış ve genel bir lojistik işgücü profil değerlendirilmesi yapılmıştır.

\section{Kavramsal Çerçeve}

\section{Lojistik Nedir?}

Lojistik yeni bir kavram gibi gözükse de hızla değişen dünyada kapsamı ve işleyişi farkl1laşan eski bir faaliyetler bütünüdür. Eski bir kavram olarak lojistik; nakliye, sevkiyat, depolama gibi anlamlarda kullanılmıştır (Tekin, 2013: 13).

İlk etapta askeri bir kavram olarak karşımıza çıkan lojistik, askerlerin ve askeri teçhizatın yerleştirilmesi ve sevkiyatı olarak ifade edilmiştir (Özdener, 2010: 4). İleryen süreçte toplumun yaşam tarzında rahatlamaya, kolaylaşmaya etki eden, ürünün ilk elden son tüketiciye kadar ulaştırılmasını optimal seviyede gerçekleştirmek için (Bölükbaş, 2016 ), doğru ürünü, miktar, şartlar, mekan, zaman, tüketici ve fiyatlama çerçevesinde en uygun biçimde bir araya getirme faaliyeti olarak ifade edilmektedir (Akçay, 2005: 34).

Lojistik malların ihtiyaç duyuldukları yere ulaştırılmaları şeklinde algılansa da sadece taşımacılık faaliyeti değildir. Teslimatın yanında her biri uzmanlık ve teknik gerektiren stoklama, depolama, faaliyet mekanı tercihi, akış ve rotalama, sipariş takibi, elleçleme, ambalajlama, teslim sonrası hizmet gibi birçok temel süreci barındıran faaliyetler bütünüdür (Erol, 2015). Lojistiğin tam olarak gerçekleşmesi için temel lojistik faaliyetlerden en az üç farklı faaliyetin art arda uzmanlaşmış bir şekilde yerine getirilmesi gerekmektedir (Babacan, 2003: 9).

Lojistikte genel kabul görmüş en yetkin organizasyon olan CSCMP tarafından oluşturulan tanımla; lojistik yönetimi, müşterilerince talep edilen her tip ürünün, bilgi ağı ve servisleme sayesinde, ilk noktadan tüketileceği nihai yere kadar, tedarik zincirindeki faaliyetlerinin etkili ve randımanlı bir şekilde tasarlanması, hayata geçirilmesi, taşınması, saklanması ve denetim altında tutulmasını sağlama hareketi olarak ifade edilmektedir (Çekerol ve Kurnaz, 2011: 50). En geniş anlamıyla "Hayatın var olmasıyla birlikte ortaya çıkan sadece üretimi değil insanı ilgilendiren her faaliyeti destekleyen, ihtiyacın tespitinden bu ihtiyacın giderilmesine ve hatta ihtiyaç giderildikten sonra elden çıkarma faaliyetlerini de içine alan, lojistiğin aksiyonları arasında yer alan en az üç sürecin işletilmesi" şeklinde tanımlanabilir (Keskin, 2009: 33-34). Lojistikte en üstte bulunan yönetimsel seviyeden, en alt seviyeye kadar tüm faaliyetlerin koordinasyon ve eşgüdüm içinde gerçekleştirilmesi amaçlanmaktadır (Akdemir, 2011: 5). 
Lojistik kavramı formüle edilirse; "Lojistik = Tedarik + Malzeme Yönetimi + Dağıtım" şeklinde yazılabilir (Rushton vd. 2006: 4). Başarılı bir lojistik için iyi planlanma yapılması gerekmektedir. Müşteriye ulaşırken en iyi kanal tasarımını ve ağ stratejisini seçme, talebi karşılamak için altyapıyı planlama, malzeme yönetimde, nakliyede ve depoda operasyonel mükemmelliğe ulaşma ve en iyi bilişim sistemleri ile ekipmanı kullanma başarı açısından önemlidir (Alamdari,2016: 6). Lojistik, alıcının beklenti ve ihtiyaçlarına cevap vermek için direkt ya da endirekt süreçteki tüm tarafları ilgilendirmektedir (Chopra \& Meindl, 2007: 3).

\section{Lojistik Sektörünün Gelişim Süreci ve Önemi}

Kökeni askeri terminolojiye dayanan, lojistiğin geçmişi binlerce y1l öncesidir. Bilimsel bakış açısıyla 1900'lü yıllarda zirai ürünlerin dağıtımında, zamanlama ve yer faydası sebebiyle lojistik sürecin hayata geçirildiği görülmektedir (Erkan, 2014: 48). Lojistik sektörü ilkel lojistik ile başlayıp, askeri lojistik, ticaret lojistiği ve son olarak da modern lojistik dönemleri şeklinde gelişmiş̧ir (Bölükbaş1, 2016).

Türkiye'de 1980 atılımıyla taşımacılık alanında yatırımlar yapıldığı, ulaştırma türlerinde altyap1 oluşturulduğu, 1990 sonrasında taşımacıllı̆ın yükselişe geçtiği görülmektedir. Dünya standartlarını yakalaması, hizmet çeşitlenmesi, sektörde etkin hale gelmesi ve dinamik, hızla gelişen, uluslararası alanda da kabul görmüş bir sektör halini alması 2000 yılından sonrasına denk gelmektedir (Babacan, 2003: 10).

Lojistik kavramı geçmişten günümüze hızla gelişmekte ve bütün ekonomiler açısından büyük önem arz etmektedir. Son y1llarda lojistik küreselleşme ve e-ticaretin gelişmesi ile çok hızlı bir şekilde büyümektedir (Schumacher vd. 2009). Yeni ekonomi anlayışı, güçlü ve acımasız rekabet ortamı ve bunun yarattığ sonuçlar, teknolojik gelişmeler, taleplerdeki yapısal farklılaşma ve değişen piyasa koşulları da değişimi hızlandırmaktadır (Şekkeli, 2016: 9-10). İlave olarak gelişmiş ülkelerin varlığı ve etkisi, farklılaşan işgücü de bu değişimde etkili olmaktadır (Orhan, 2014: 88-90). Siyasal olaylar, sosyal olgular, üretimdeki değiş̧imler, kültürel etki, askeri alandaki değişimler de etki eden faktörler olarak sayılabilmektedir (Tekin, 2013: 12). İnternetin ve akıllı iletişim araçlarının yaygınlaşması alışveriş alanlarını değiştirse de satın alınan ürünlerin taşınması ve lojistiğine yönelik ihtiyaç her zaman devam etmektedir.

Gelişen lojistik ülkenin üstünlük yarışında, önemli kalemlerden birini oluşturmaktadır. Dünya ticaretinin bel kemiği olan lojistik sektörü, istihdamda geniş kaynak oluşturması yanında sanayi sektöründe de fark yaratarak ülkenin ekonomik gücüne katkı sağlamaktadır. Ayrıca malın üretim öncesi siparişi, üretim sonrası depolanması, dağıtımı, gümrükleme ve sigortalama işlemleri, ambalajlama gibi tüm faaliyetlerin yerine getirilmesi, sanayi firmalarına maliyet, hız ve esneklik avantajı kazandırarak kıyasça üstünlük kazandırmaktadır (Koban ve Keser, 2013: 32-43). Lojistik rekabette güç, ülkenin lojistik imkan ve tecrübelerine dayanmaktadır. Malın ve mesafenin aynı olduğu bir teslimat süresi Kazakistan'da 93 günken, İsveç’te bu teslimat 6 günde gerçekleşmektedir. Bu bağlamda lojistik faaliyetlerin performansı ve kalite üstünlüğü de ülkelere göre değişmektedir (Bayraktutan \& Özbilgin, 2015: 99).

Lojistiğin amacı; stokta minimum mal tutarak, bu malların en az sapma ve hata payı ile optimum kalitede hizmet vererek, ürünün alıcıya ulaşımını sağlamaktır. Faaliyetler süresince müşteri memnuniyeti ve başarı önemlidir (Bölükbaşı, 2016). Lojistik, kapsam olarak geniş bir faaliyetler bütününü ifade etse de Türkiye'de de gelişme sürecinde olan ülkelerde olduğu gibi daha çok taşımacılık üzerine odaklanmış bir sektör olarak ele alınmaktadır (Adal, 2015: 158).

Dünya çapında seçilmiş bazı OECD ülkeleri ile karşılaştırıldığında Türkiye ulaştırma ve depolama sektörünün hizmetler üretimindeki payının gelişmiş ülkelere göre, kıyasça daha yüksek orana sahip olduğu ifade edilmektedir (Koru \& Dinçer, 2018: 5). Bu durum gelecek vaat eden bir sektör olduğuna ve ülke ekonomisindeki önemine de işaret etmektedir. 


\section{Türkiye'de Lojistik Sektörünün Genel Durumu}

2023 yılı hedeflerinde 500 milyar dolara ulaşması beklenen ihracat için Türkiye'de en elzem sektörlerden birinin lojistik sektörü olduğu söylenebilmektedir. Türkiye'nin milli lojistik kapasitesi yanında, Karadeniz'e sınırı olan komşu ülkeler, Orta Asya ülkeleri ve Orta Doğu ülkeleri merkezinde yer alması, kıta birleştirici özelliği dikkate alındığında, doğu ile batı ekseninde ticari dinamiklerle canlanan İpek Yolu lojistik pazarı da Türkiye'nin yüksek potansiyelini oluşturmaktadır (Bayramoğlu, 2014: 138-139).

Türkiye'de 2017 yılında 300 milyar TL olan lojistik sektör büyüklüğü, 2018 yılında 372 milyar TL'ye yükselerek GSYH'nin yaklaşık yüzde 12'sine denk gelmektedir. Bu sonuç sektörün Türkiye ekonomisi için önemini de göstermektedir. 2018 yılı mal bedeline göre taşımacılık oranları denizyolu taşımacılığında yüzde 65 , havayolu taşımacılığında yüzde 12 , karayolu taşımacılığında yüzde 22, demiryolu taşımacılığı ise yüzde 1 oranında gerçekleştiği hesaplanmaktadır (www.lojistikcilerinsesi.biz).

Dünya Bankası tarafından 2007 yılından bu yana ülkelerin lojistik performansları altı farklı ölçüte göre değerlendirilerek Uluslararası Lojistik Performans Endeksi (LPI) adı altında puanlanmaktadır. Periyodik olarak iki yılda bir yapılan bu çalışma, uluslararası ticaret ile lojistik sektörünün bağlantısını ve standardını ortaya koyan bir çalışmadır (www.utikad.org.tr).

Tablo 1: Türkiye'nin Y1llara Göre Lojistik Performans Endeksi

\begin{tabular}{ccccccccc}
\hline Yıl & Sıra & $\begin{array}{c}\text { LPI } \\
\text { Puanı }\end{array}$ & Gümrük & Altyapı & $\begin{array}{c}\text { Uluslararası } \\
\text { Sevkiyat }\end{array}$ & $\begin{array}{c}\text { Lojistik } \\
\text { Hizmetlerin } \\
\text { Kalitesi }\end{array}$ & $\begin{array}{c}\text { Gönderilerin } \\
\text { Takibi ve } \\
\text { Izlenebilirliği }\end{array}$ & $\begin{array}{c}\text { Gönderilerin } \\
\text { Zamanında } \\
\text { Teslimi }\end{array}$ \\
\hline $\mathbf{2 0 1 0}$ & 39 & 3,22 & 2,82 & 3,08 & 3,15 & 3,23 & 3,09 & 3,94 \\
\hline $\mathbf{2 0 1 2}$ & 27 & 3,51 & 3,16 & 3,62 & 3,38 & 3,52 & 3,54 & 3,87 \\
\hline $\mathbf{2 0 1 4}$ & 30 & 3,5 & 3,23 & 3,53 & 3,18 & 3,64 & 3,77 & 3,68 \\
\hline $\mathbf{2 0 1 6}$ & 34 & 3,42 & 3,18 & 3,49 & 3,41 & 3,31 & 3,39 & 3,75 \\
\hline $\mathbf{2 0 1 8}$ & 47 & 3,15 & 2,71 & 3,21 & 3,06 & 3,05 & 3,23 & 3,63 \\
\hline \multicolumn{7}{c}{ Kaynak: UTIKAD }
\end{tabular}

Yukarıdaki Tablo 1 'de görüldüğü üzere 2018 y1lı ölçümüne göre Türkiye'nin 160 ülke arasında önceki dönem değerlendirmesine göre 34. sıradan 47. sıraya gerilediğini görülmektedir. Yıllar içindeki değerlendirmeler karşılaştırıldığında 2018 y1lında genel durum içinde en düşük performansın gösterildiği anlaşılmaktadır. 2016 yılı baz alındığında Türkiye'nin değerlendirmeye konu olan altı kriterin hiç birinde ilerleme kaydedemediği hatta önemli ölçüde düşüş yaşadığ görülmektedir. Lojistik Performans Endeksinde Türkiye'ye sıra kaybettiren etmenlerin başında gümrük kriterleri gelmektedir. Gümrükteki tıkanıklıklar, mevzuat boşluklarının bu düşüşte etkili olduğu sektörce bilinmektedir. Değerlendirilen bir başka kriter ise lojistik hizmetlerin kalitesidir. Bu kriterde de Türkiye 2018 yılında, 2016 yılına göre sıra kaybederek olumsuz bir imaj görüntüsü vermektedir. Bu durum uluslararası arenada ticari koridor alternatif arayışında Türkiye adına olumsuz bir tablo çizmektedir (www.utikad.org.tr). Bu sonuçların düzeltilmesi ve Türkiye'nin sıralamada daha üst noktalara ulaşabilmesi için gerek firmalar bazında gerek ülke politikaları bazında ciddi adımların atılması gerekmektedir. 2023 yılı hedefinde Lojistik Performans Endeksi sıralamasında Türkiye'nin 25. sırada olması hedeflenmektedir.

Lojistik Performans Endeksi y1llara göre değerlendirildiğinde sıralamada üstte bulunan ülkeler ile kötü karne sergileyen ülkeler arasındaki farkın giderek artı̆̆ı görülmektedir. Bu durumun en önemli sebepleri olarak, politik gerginlikler, geri kalmışlık, istikrarsız iktisadi yapı, altyapısal sorunlar ve küreselleşmeye dahil olamama sayılmaktadır. Bütün bu kriter değerlendirmeleri ve puanlamalar daha etkin ve entegre bir uluslararası ticaret yaratma amaciyla yapılmaktadır (Demirbilek, 2018: 32-33). 
2009 sonrası dönemde küresel ve lokal gelişmeler sektörün istikrarlı bir büyümesinin önündeki en büyük engellerden biri olarak görülmektedir. Global ticaretteki korumacı politikalar yanında Ortadoğu'da devam eden güvensiz ortam Türk taşımacılık ve lojistik sektörünün gelişmesini sinırlandırmaktadır.

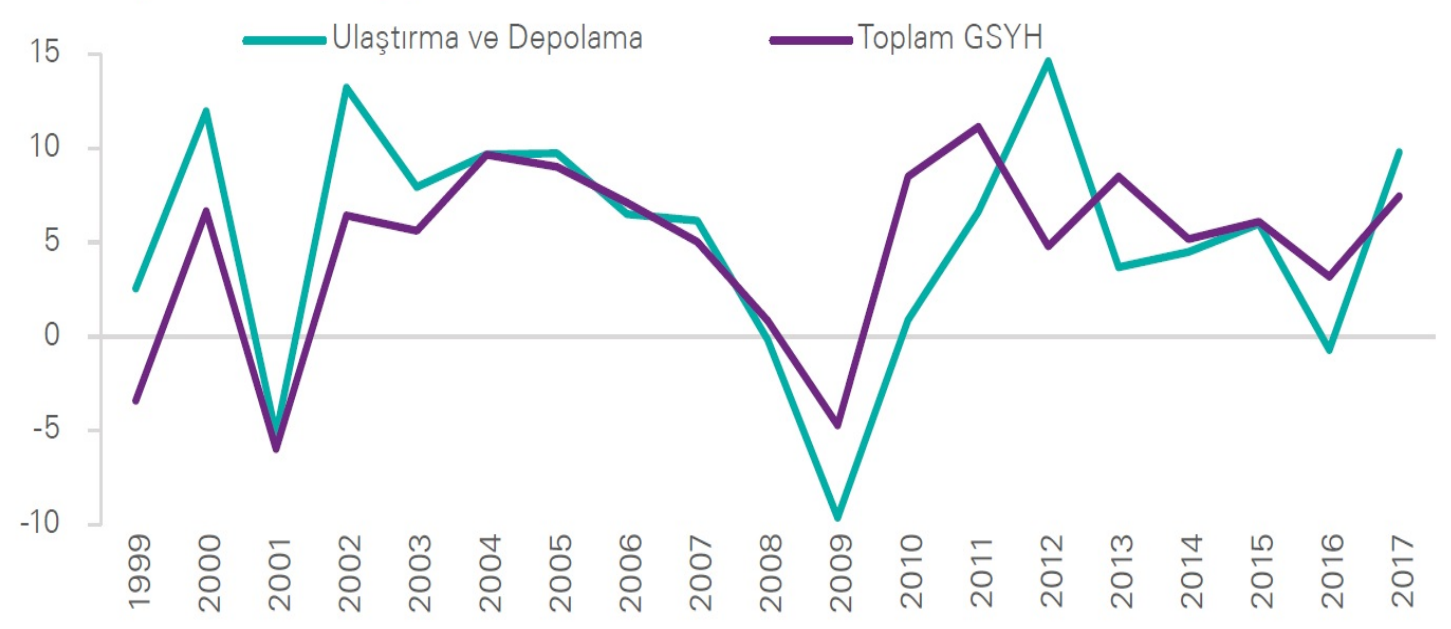

Şekil:1 Y1ll1k Büyüme

Kaynak: KPMG(2019)

Yukarıdaki Şekil 1 'e göre 2012 sonrasında ise içinde bulunduğu coğrafyadaki gerilim, sektörün GSYH'ya kıyasla yavaş seyretmesine sebep olmaktadır. Özellikle 2016 yılındaki terör saldırıları turizm sektörüyle beraber güvenliğin önemli olduğu taşımacılık ve lojistik sektörünü de olumsuz etkilemiştir. Sonuç olarak 2012-2017 döneminde genel GSYH'da büyüme yüzde 6,1 olarak gerçekleşirken, ulaştırma ve depolama sektöründe yüzde 4,6 seviyesinde kalmıştır (KPMG, 2019).

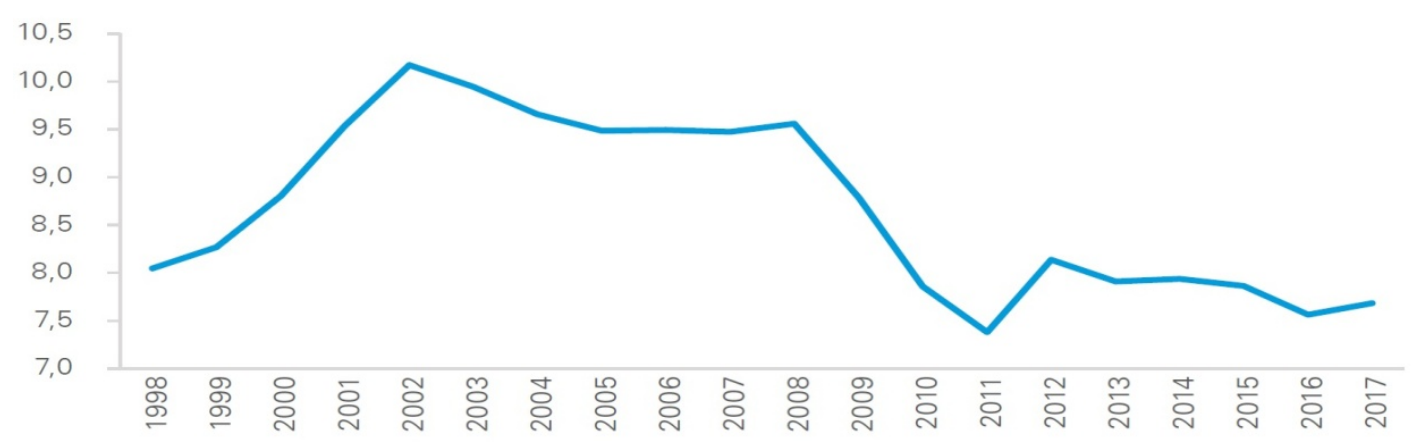

Şekil 2: Ulaştırma Depolama Sektörünün GSYH İçindeki Payı

Kaynak: KPMG (2019)

Yukarıdaki Şekil 2'de görüldüğü gibi 2012 sonrası dönemde ulaştırma ve depolama sektörünün GSYH içindeki payının düşük seyrettiği görülmektedir.

Lojistik sektörü turizmden sonra en fazla parlayan ve uluslararası arenada ülkenin fark yaratmasını sağlayan sektördür. Fark yaratabilmek için devlet politikalarının ve mevzuatın lojistik temelini oluşturan taşımacılık faaliyetini geliştirecek ve bütün gümrük kapılarının da iyileştirilmesi sağlayacak şekilde hayata geçirilmesi gerekmektedir (Çekerkol \& Kurnaz, 2011: 53). 
10. Kalkınma Planı kapsamında "Taşımacılıktan Lojistiğe Dönüşüm Programı ve Eylem Planı" da yer almaktadır. Programın amacı lojistik maliyetlerin global düzeyde yarışacak seviyeye çekilmesi, sanayi ürünlerinin maliyetinde lojistik kaynaklı giderlerin düşürülmesi ve lojistiğin Türkiye'nin istikrarlı ekonomik büyümesi içindeki payının arttırılması şeklindedir (Kalkınma Bakanlığı, 2013: 110-111).

Lojistik faaliyetler en çok otomotiv, gıda ve perakende sektörlerinde kullanılmaktadır. Sektör değerlendirildiğinde, dünya kalite standartlarında varlık gösterebilecek lojistik şirketlerin az sayıda olduğu, sektörde faaliyet gösteren firmalarda personel devir hızının fazla ve bilgi kullanımının yetersiz olduğu görülmektedir (www.odd.org.tr).

Günümüzde lojistik sektörü, gelişmeleri anlık takip edebilmekte, Dünya çapındaki ünlü lojistik firmaları Türkiye lojistik pazarına kolaylıkla girebilmekte, Türk firmalarına lojistik çözümler bulabilmektedirler. Türkiye genç ve dinamik nüfusu ve sektöre verdiği önem neticesinde dünya üzerinde önemli bir üs olabilecek pozisyondadır (Daşkan, 2016:4). Lojistik sektörü, ekonomik olarak sağladığı faydalar yanında toplumun gelişmişlik düzeyini yükseltme ve refahı arttırma gibi yan roller de üstlenmektedir (Erkan, 2014: 48).

Tablo 2: 11. Kalkınma Planı Lojistik Hedefler

\begin{tabular}{lll}
\hline & $\mathbf{2 0 1 8}$ & $\mathbf{2 0 2 3}$ \\
\hline Lojistik Performans Endeksinde Türkiye'nin Sırası & 47 & 25 \\
\hline Toplam Yük Taşımacılığı İçerisinde Demiryolunun Payı & 5,15 & 10 \\
\hline Demiryolu Hat verimliliği & 1,48 & 2,77 \\
\hline Demiryolu ile Taşınan Yük Miktarı & 14,5 & 32,4 \\
\hline Elektrikli Hat Oranı (\%) & 43 & 77 \\
\hline Sinyal Hat Oranı (\%) & 45 & 77 \\
\hline İltisak Hattı Uzunluğu & 433 & 727 \\
\hline Toplam Konteyner Elleçlemesi & 10,8 & 13,5 \\
\hline Havayolu Dış Hat Toplam Kargo Trafiği & 1.355 & 1.529 \\
\hline \multicolumn{2}{c}{ Kaynak: On Birinci Kalkınma Planı } &
\end{tabular}

Türkiye'nin her alanda verimini artırmak, uluslararası düzeyde rekabet gücü sağlayabilmek, risk ve tehditlere karşı firsat yaratabilmek amacıyla hazırlanan On Birinci Kalkınma Planı (20192023) her alanda olduğu gibi lojistik ve ulaştırma sektörü hedefleriyle, lojistik maliyetlerin azaltılması ve buna bağlı verimliliğin ve rekabetçiliğin artırılmasını amaçlamaktadır. Yukarıdaki Tablo 2 ile 2018 y1lı verileri ile On Birinci Kalkınma Planı 2023 y1lı lojistik hedef verileri karşılaştırılmaktadır (11. Kalkınma Planı (2019-2023):76).

\section{İşgücü Nedir?}

İşgücü halihazırda istihdam edilenler ile işsizlerin toplamını ifade etmektedir. İşsiz nüfusun, çalışabilir 15 yaş ve üzeri kısmı, çalışmaya hazır ve istekli (iş arayan) kısmı işgücü içerisinde sayılmaktadır. İş talebi olmayan, çalışmak istemeyen ve çalışacak durumda bulunmayanlar (işgücüne dâhil olmayan nüfus) bu istatistiğin dışındadır (https://piyasarehberi.org).

Küreselleşme ile birlikte değişen işgücü piyasaları, dünya ekonomisini kuralsızlaştırması, üretimdeki değişme, işgücündeki yapısal değişim işsizliğin artmasına sebep olmaktadır. Günümüzde kronik işsizliğin hüküm sürdüğü, gelişmekte olan ülkelerde işsizlikle yoksulluğun aynı şeyi ifade ettiği görülmektedir. Dünyada üretim artarken ters orantıda istihdam azalmakta ve çalışan başına düşen emek de artmaktadır (Baştaymaz, 1998: 21). Teknolojik gelişmeler yüksek vasıflı işgücü ihtiyacını artırmakta, vasıfsız ya da daha az vasıflı işgücüne olan talep azalmaktadır. İşsizlik sorunu kadar nitelikli işgücünü bulmak ve istihdam etmek de sorun teşkil etmektedir (Uyanık, 2008: 209224). 
Türkiye'de işgücü piyasaları incelendiğinde ve gelir düzeyinde benzerlik gösteren ülkelerle karşılaştırıldığında, tarımsal istihdamın kontrolsüz büyüklüğü, emekte arzın fazla talebin yetersiz olması, genç, deneyimsiz ve niteliksiz işgücü fazlalığı temel sorunlar olarak karşımıza çıkmaktadır (Çondur \& Bölükbaş, 2014: 77-93).

\section{Türkiye'de Genel İşgücü Profili}

Türkiye'nin son elli yılında ana sektörler arasında önemli geçişler olduğu görülmektedir. Giderek artan köyden kente taşınma, tarımdan hizmetler sektörüne istihdam kaymalarını beraberinde getirmiştir. Türkiye ekonomisinde hizmetler sektörü giderek önem kazanmıştır (Koru \& Dinçer, 2018: 5).

Türkiye'de işgücü piyasasını yorumlarken kullanılacak en önemli gösterge nüfustur. İşgücü arzını etkileyen unsurlar nüfus dinamikleri tarafından belirlenirken nüfusun sayısal değeri ile birlikte, bireylerin işgücüne katılma istekleri ve çalışma süresi beklentileri de toplam işgücü arzını belirlemektedir (Tansel, 2012). Nüfus, işgücü ve istihdam doğru orantıda artmaktadır. 2018 yılının ilk yarısında tek haneli rakamları gören işsizlik oranı, ikinci yarıda ekonomideki yavaşlayan büyüme oranlarıyla birlikte artış eğilimine girmiştir. TÜİK'in İşgücü İstatistiklerine göre 2018 yılında işsizlik oranı bir önceki yıla göre 0,1 puan artarak yüzde 11 olarak gerçekleşmiştir. İstihdam edilenlerin sayıs 2018 yılında, geçen yıla göre 549 bin kişi artarak 28 milyon 738 bin kişi olurken istihdam oranı ise 0,3 puanlık artış ile yüzde 47,4 oranında gerçekleşmiştir. İşgücüne katılım oranı 2018 yılında 0,4 puan artışla yüzde 53,2 oranında gerçekleşmiştir (TÜIKK, 2019).

2018 y1lında toplam istihdam içinde hizmetler sektörünün payı 2017 y1lına göre 0,8 puan artarak \% 54,9'a yükselmiştir. Hizmetler sektörü 528 bin kişiye ek istihdam sağlayarak istihdama en büyük katkıyı vermiş, ulaştırma ve depolama sektörü ise toplam istihdam içindeki payı aynı kalmakla birlikte, 20.000 kişiye ek istihdam sağlamıştır. (Tobb, 2018: 205)

Türkiye 2019 y1lı temmuz ayı verilerine göre, işsizlik oranının artarak \%13,9 sevilerine çıktığ 1 , istihdam oranın $\% 46,4$ işgücüne katılma oranın $\% 53,8$ olarak gerçekleştiği, tarım sektörü hariç kayıt dışı çalışanların oranının \%23,2 olarak gerçekleştiği görülmektedir (TÜİK, 2019).

\section{Lojistik Sektöründe İşgücü}

Lojistik sektörün gelişiminde insan kaynağının vasfı, fiziksel altyapı, bilgi teknolojisi ve iletişim kriterlerinden önce geldiği ifade edilmektedir. (Van Hoek \& Harrison, 2011:1-10) Lojistik, komplike yapıs1 gereği, insan gücü, teknolojik gelişim, enformasyon, sürdürülebilir eğitim unsurlarının tümünü kapsamaktadır. Küreselleşmenin her alanda olduğu gibi ticarete de hareketlilik kazandırmasıyla, lojistik sektörünün önemi ve dünya çapındaki etkileri daha dikkat çeker hale gelmektedir. Lojistik sektörünün dünya ticaretindeki payı \%30 civarlarındadır (Tufan, 2019: 675).

Lojistik sektörü, istihdam yaratma açısından en önemli hizmet sektörlerindendir. Rekabet yeteneğinde, nitelikli işgücü büyük öneme sahiptir. İyi yetişmiş ve uzmanlaşmış çalışan, yönetim süreçlerinde profesyonelleşmede, piyasa koşullarına hakim olabilmede ve tüketici taleplerine daha kolay adapte olabilmede, kalitede gelişmede, maliyeti düşürmede etkin rol oynamaktadır (Koban \& Keser, 2013: 32-43). Özellikle yönetici konumunda çalışanların, sektörün ve çağın ihtiyacı olan mesleki yetkinlik için, bilgi ve becerilerle donanımlı olmaları gerekmektedir. Küresel değişimle ve gelişimle birlikte bu yeteneklerin önem dereceleri de farklılık göstermektedir (Çakaloz \& Tuna, 2013: 23). Lojistik operasyonların başarısı örgütte lider bir yöneticinin bulunmasına ve ekibin başarısına bağlıdır (Kaya, 2013: 232).

Lojistik firmaları, yenilikçi, çok yönlü düşünen, deneyimli, eğitiminde kalite ve farklılaşmayı sağlayabilen çalışanları tercih etmektedir (Akar \& Çakır, 2016: 185). Bu amaçla üniversitelerde sektörle ilgili programlar açılmasına rağmen, istihdam problemi devam etmektedir. Problemin çözülebilmesi, eğitimli işgücünün deneyim kazanmasına imkan tanımakla mümkün 
olabilecektir. Sektördeki firmaların bu alanda eğitim alan gençlere uygulama imkânı tanıması ve başarılı mezunları sektöre kazandırmak için özendirmeleri, sektörün rekabet gücüne katkı sağlayacak çalışmalardır (Çekerkol \& Kurnaz, 2011: 58). Önümüzdeki dönemde lojistik sektörünün insan merkezli olma özelliğinin devam edeceği ancak eğitim konusunda sektörde ciddi eksikler olduğu ve bilgi temelli öğrenme ihtiyacının artacağı, iş ile ilgili yeteneklerden daha önemlisi çalışanların "değer yaratma kabiliyetlerinin" geliştirilmesinin önemli olacağı gözükmektedir. Lojistik sektörü genel olarak erkek egemen bir sektör olmasına karşın kadınların da alandaki varlığ geçen gün artmakta ve bu durum desteklenmektedir (Asyalı \& Tuna,2015).

Lojistik sektöründe çalışanlar farklı alanlarda istihdam edilebilmektedirler. Bu alanlardan bazıları; lojistik analiz, planlama ve ar-ge, satın alma ve ambar yönetimi, uluslararası lojistik planlama, nakliye ve rotalama, tedarik zinciri yönetimi, müşteri ilişkileri yönetimi, üretim planlama, satış ve lojistik mühendisliği olarak örneklenebilmektedir (Koban \& Keser, 2013).

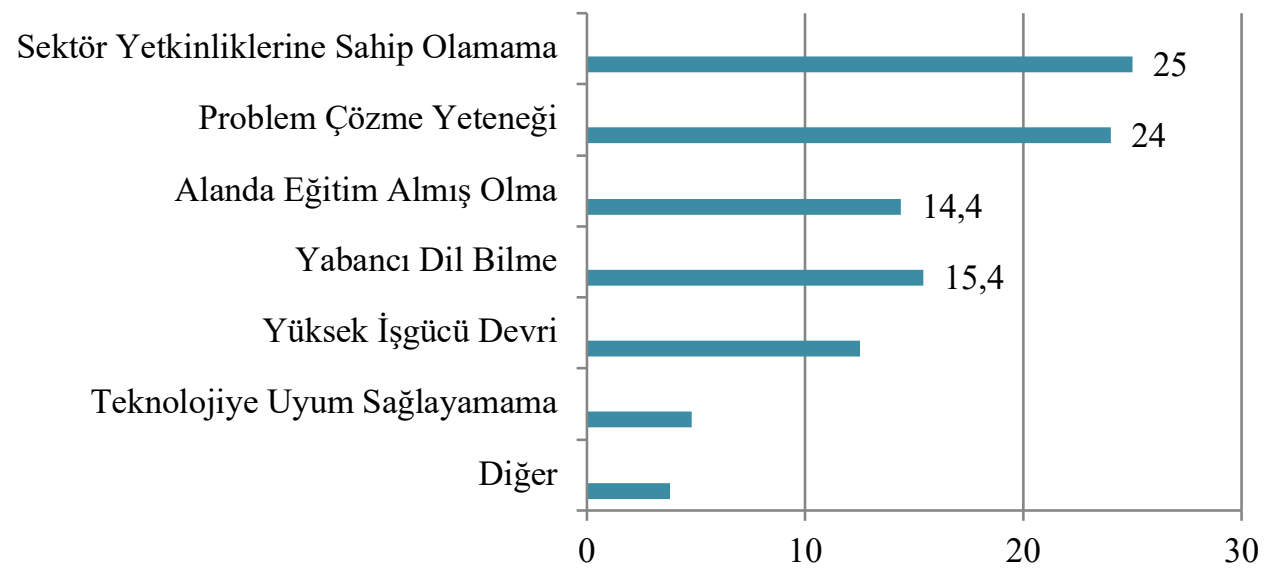

Şekil 3: Lojistik Sektörü Çalışan Sorunları Kaynak: ULUK,2018

Yukarıdaki şekilde belirtildiği gibi, ulaştırma ve lojistik sektöründe işgücünün en büyük sorunu olarak \%25 oran ile "sektörde çalışmak için gerekli yetkinliklere sahip olamama" ilk sıradayken \%24 "lük yakın oranla "analitik düşünme, problem çözme yetkinliklerine sahip olamama" en yüksek değerli ikinci sorun olarak dikkat çekmektedir (ULUK, 2018: 9-23).

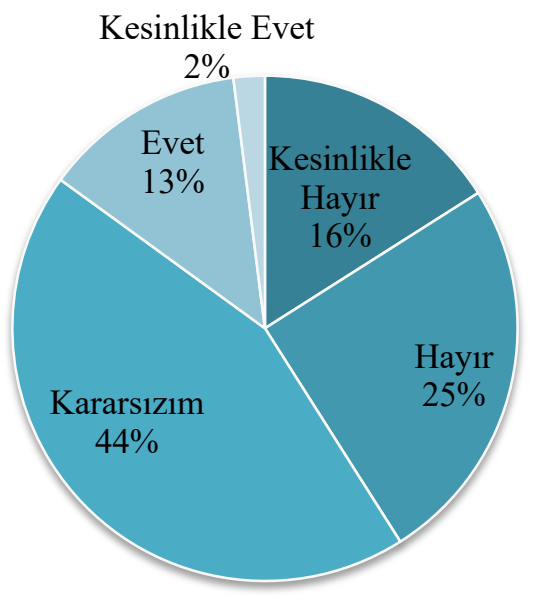

Şekil 4: Lojistik Sektörü Çalışanlarının Eğitimin Yeterliliği (\%)

Kaynak: ULUK,2018 
Şekil 4'de belirtildiği üzere lojistik sektöründeki firmaların çalışanlarının eğitim yeterliliği ile ilgili görüşleri $\% 44$ oranla kararsız, $\% 25$ oranla hayır şeklinde olup eğitim alanında sektörün yetersizliği vurgulanmaktadır. Nitelikli iş gücü yaratmanın ve günceli yakalamanın önemli olduğu lojistik sektöründe eğitimin önemli unsurlardan biri olduğu yadsınamamaktadır.

Lojistik sektöründe uluslararası rekabet düzeyinin ve lojistik performansının arttırılmasında en önemli faktör sıralamasında teknik bir konu olan altyapının güçlendirilmesi ilk sırada yer alırken, hukuki zeminin geliştirilmesine yönelik lojistiğe yönelik ortak yasal mevzuatın oluşturulması ikinci önemli faktör, lojistik sektöründe çalışacak insan kaynağının desteklenmesi ise üçüncü önemli faktör olarak siralanmaktadır (ULUK, 2018).

\section{Lojistik Sektörü İşgücü Profilinin Diğer Sektörlere Göre Değerlendirilmesi}

Lojistik sektörü faaliyetleri gereği teknoloji ve emeğin iç içe geçtiği bir sektördür. Sektördeki firma sayısının sürekli artması, mevcut firmalarında hizmet sahalarını geliştirmeleri bu alandaki istihdam ihtiyacını artırmaktadır. Özellikle kent insanı için sektör önemli bir firsattır. İstihdam edilen kişiler, kendi alanlarılla ilgili eğitim almış olmalarıyla birlikte, niteliklerini korumak için sürekli eğitime tabi tutulmaktadırlar (Koban \& Keser, 2013: 34). Hizmet ve firma çeşitliliği olarak çok farklı faaliyetlerle yürütülen lojistik sektöründe çalışma ilişkilerinde de oldukça karmaşık bir yapı görülmektedir.

Sektörde istihdam edilenlerin önemli bir kısmı devamlı hareket halinde olan kara, hava ve deniz taşıtlarında görev yapmaktadır. Bunların çalışma koşulları fiziki farklılıklar gösterdiği gibi, taşıma yapıları olarak kendi aralarında da farklı özellikleri kapsamaktadır. Bu farklılıklar lojistik sektöründeki mevzuatın da oldukça geniş bir yelpazede düzenlenmesini zorunlu hale getirmektedir (Adal, 2015:159). Türkiye'de lojistik sektöründe çalışan profili, sektöre girip deneyim ve bilgi edinen ve kazandığı bu donanımla sektöre yeni katılan çalışanları eğiten usta çırak ilişkisine benzer bir yapı içinde gelişmektedir. Sektör, bünyesinde çalışan insan kaynaklarından teorik bilgi ile pratik bilgiyi bütünleştiren, sürekli gelişim ve değişim içinde olan profil talep etmektedir (Oda, 2008: 56).

Tablo 3: Sektörlere Göre İstihdam Durumu

\begin{tabular}{llll}
\hline Sektör & $\begin{array}{l}\text { Erkek Çalışan } \\
\text { Sayısı }\end{array}$ & $\begin{array}{l}\text { Kadın Çalışan } \\
\text { Sayısı }\end{array}$ & $\begin{array}{l}\text { Toplam } \\
\text { Çalışan Sayısı }\end{array}$ \\
\hline İmalat & 2.570 .619 & 783.823 & 3.354 .443 \\
\hline Toptan ve Perakende Ticaret & 1.612 .609 & 568.279 & 2.180 .888 \\
\hline İnşaat & 1.076 .385 & 121.113 & 1.197 .498 \\
\hline Konaklama ve Yiyecek Hizmeti Faaliyetleri & 514.987 & 212.774 & 727.762 \\
\hline Ulaştırma ve Depolama & 609.470 & 80.235 & 689.706 \\
\hline İdari ve Destek Hizmet Faaliyetleri & 358.428 & 163.297 & 521.725 \\
\hline İnsan Sağı̆̆̆ ve Sosyal Hizmet Faaliyetleri & 102.256 & 174.807 & 277.060 \\
& & & \\
\hline Ĕğitim & 111.246 & 159.738 & 270.984 \\
\hline
\end{tabular}

Kaynak: İPA 2018

Tablo 3' deki veriler 1şığında ulaştırma depolama sektörü çalışan sayısı, imalat, toptan ve perakende ticaret, inşaat, konaklama ve yiyecek hizmetleri sektörlerinden sonra en fazla olan sektör olduğu görülmektedir. Eğitim ve sağlık sektörlerinde kadın çalışan sayısı erkeklere göre fazlayken imalat, toptan ve perakende ticaret, inşaat, konaklama, ulaştırma ve depolama, idari hizmetler sektörlerinde erkek çalışanların gerisindedir. İ̧̧e göre fiziksel gücün gerekli olduğu ve yoğun çalışma gerektiren ulaştırma ve depolama sektörlerinde kadın çalışanların azlığından ve genelde erkek egemen çalışan profilinden bahsedilebilmektedir.

Sektörlerin vardiyalı çalışma durumu incelendiğinde, işyeri büyüklüğü arttıkça vardiyalı çalışma oranı artmakla birlikte elektrik, gaz ve buhar üretimi/dağıtımı sektöründe en fazla vardiyalı 
çalışan varken ulaştırma ve depolanma sektöründe ise $\% 7$ civarlarında seyretmektedir. Bu oran ile finans ve sigorta faaliyetleri sektörü ile eğitim sektöründen daha fazla vardiyalı çalışan bulunmaktadır. İSKUR hizmetlerinden yararlanma durumunda, eğitim sektörü en fazla yararlanan sektörken, ulaştırma ve depolama sektörü, imalat, sağlık, finans, konaklama, toptan ve perakende ticaret sektörlerine göre daha az yararlanmaktadır (IPA, 2018). Lojistik sektöründe faaliyet gösteren firmalarda personel giriş- çıkış süresi kısa olup aynı çalışan uzun süreli olarak istihdam edilememektedir (www.odd.org.tr).

\section{Karaman İli Lojistik Sektörü İşgücü Profilinin Değerlendirilmesi}

\section{Çalışmanın Amacı}

$\mathrm{Bu}$ çalışma ile genel lojistik faaliyetler ve lojistik işgücü profili verileri ışı̆̆ında Karaman ili lojistik sektörü çalışanlarının profil değerlendirilmesi amaçlanmaktadır. Lojistik faaliyetlerde bulunan firmalarla yapılan çalışmada çalışanların cinsiyet, eğitim, medeni durum ve tecrübe gibi kriterler üzerinden değerlendirilmesi yapılarak genel lojistik sektörü çalışan profili ile benzerlik gösterip göstermediği ve profilin güçlü ve zayıf yönlerinin neler olduğunun tespiti amaçlanmaktadır.

\section{Çalışmanın Kapsamı ve Yöntemi}

Üretime dayalı güçlü sanayisi, gelişmekte olan bir il olması, coğrafi konum gereği geçiş noktası üzerinde bulunması nedeniyle lojistik sektörü için gelecek vaat etmesi, genç ve dinamik nüfusu ve yüksek istihdam oranı gibi sebeplerden dolayı Karaman İli çalışma bölgesi olarak seçilmiştir. Çalışmaya esas olmak üzere bünyesinde lojistik faaliyet bulunan 6 firmanın insan kaynakları departmanı ile görüşülmüştür. Gıdaya dayalı üretim firmalarında hem toplam çalışan profili hem de lojistik faaliyetlerde çalışan profiline ait çalışmalar yapılmıştır.

Çalışılan firmalardan 4 tanesi gıda üretimine dayalı faaliyet gösteren ilin büyük firmaları olup diğer 1 firma ilin en eski gıda toptancısı, diğer firma ilin tek atık toplama ve ayrıştırma firmasıdır. Firmaların farklı çalışma sahaları olsa da yapılan lojistik faaliyetlerin benzerliği çalışan profilleri üzerinden genelleme yapılmasına imkan vermektedir. Karaman ili ekonomik ve demografik yapısı hakkında kısaca bilgi verilerek, firma özelinde lojistik faaliyetlerinde çalışanlara ait profil bilgileri verilerek genelleme yapılarak sonuca ulaşılmıştır.

\section{Çalıșmanın Kısıtlııkları}

Karaman ilinin küçük bir il olması, kişisel tanınırlığın yüksekliği, çoğu firmanın aile şirketi olmasından kaynaklı kapalı yapısı nedeniyle mali verilere ve detaylı bilgilere ulaşılması sınırlı kalmıştır. Firma istekleri doğrultusunda firma adı paylaşılmamış, firmaların isimleri bu nedenle kodlanarak verilmiştir. Firma faaliyet alanı, kapasitesi ve tarihçesi hakkında genel bilgiler verilmiştir. Firma özelinde alınan işgücü profil bilgileri üzerinden genellemeler yapılmıştır.

\section{Çalışmanın Önemi}

Günümüz dünyasında gittikçe önem kazanan ve her sektör ile ilişki içinde olan lojistik sektörünün hız, kalite, verimlilik ve kazanç açısından rekabet edebilir olmasında en önemli etkenlerden biri şüphesiz insan faktörüdür. Donanımlı işgücü her sektörde olduğu gibi lojistik sektöründe de artı değer yaratan özelliğiyle iyi değerlendirilmelidir. Bu çalışma ile Karaman ilinin lojistik sektörü işgücü bakımından değerlendirilmesiyle mevcut durum belirtilerek güçlü ve zayıf yönlerinin değerlendirilerek işgücünden en yüksek seviyede yararlanılması amaçlandığından önemlidir. Lojistik sektöründe doğru istihdamın ekonomik olarak doğru orantıda fayda sağlayacağ1 da bilinen bir gerçektir.

\section{Karaman İli Ekonomik ve Demografik Yapısına Genel Bakış}

Karaman, Türkiye'nin en çok nüfusa sahip ilk 10 şehrinden 6 tanesinin merkezinde bulunması, kara ve demiryolu ile 3 saat içinde on beş milyon kişiye ulaşabilme olanağına sahip 
olması, Türkiye'nin en büyük limanı olan Mersin Limanına 2 saatlik mesafede olması, en düşük deprem kuşağı olan 5. derece deprem bölgesinde olması nedeniyle deprem riski en az olan şehir olması,Teşvik Sisteminde 3. Bölge desteklerinden yararlanıyor olması, düz arazi üzerine konumlanmış olması ve elverişli iklim koşulları ile her dönem yatırımcıların ilgisini çeken bir şehir olduğu bilinmektedir (www.ktso.org.tr - a).

2018 Adrese dayalı Nüfus Kayıt Sistemine göre, merkez ve ilçeler dahil toplam nüfusu 251.913 olan ilde nüfusun yaklaşık \%74 şehir merkezlerinde, \%26 ise köylerde ikamet etmektedir. Şehir merkezlerinde nüfusun fazla olmasının nedeni olarak, iş olanaklarının ve sanayi istihdamının fazla olması, köylerde miras yoluyla azalan tarlaların geliri olumsuz etkilemesi ve şehir yaşantısının avantajları sayılabilmektedir (www.karaman.gov.tr).

İlde genç nüfus olana 35 yaş altı grup genel nüfusun yaklaşı \%53 'ünü oluşturmaktadır. 1564 yaş arası çalışma çağındaki nüfus, toplam nüfusun \%66,95 'ini oluşturmaktadır. Karaman'da Sosyal Güvenlik kapsamında 68.227 kişi çalışmakta olup 2017 verilerine göre ilköğretim, lise ve yükseköğrenime sahip olan 15 yaş üstü nüfusun toplam nüfus içindeki payının yaklaşık \%91,6 olduğu ifade edilmektedir (www.ktso.org.tr -b).

Karaman gida imalat sanayisi içinde kek, bisküvi, çikolata gofret sektöründe ülke içinde önemli bir paya sahip olup bu ürün grubu için ülke toplam üretiminin \%35'inin Karaman'da üretildiği söylenebilmektedir. Tarıma dayalı sanayinin geliştiği il, hububat ve bakliyat üretimi ve ticaretinde de gelişmiş illerden biridir. Bulgur üretimine bakıldığında ülkede üretilen toplam bulgurun \%20 'si, ihraç edilen bulgurun ise \%80 'inin Karaman'da üretildiği görülmektedir. Elma üretiminde sertifikalı elma ağaç sayısı bakımından Karaman, Türkiye'de 1. sırada, elma üretim miktarında ise \%15'lik pay ile 2. sırada yer almaktadır. Karaman Organize Sanayi Bölgesi (OSB) Türkiye'de bulunan 326 adet OSB içinde büyüklüğü bakımından, 1026 hektar alan ile 13. sırada, kişi başına düşen alan bakımından 7. sırada, toplam çalışan sayısı bakımından 11.800 kişi ile 23. sırada yer almaktadır. Karaman'dan yaklaşık 150'nin üstünde ülkeye ihracat yapılmaktadır. İlde demiryolu lojistik merkezi kurulması projesi ile de Karaman ekonomisinin ve sanayisinin gelişiminin artması beklenmektedir. Projenin ön çalışmasına göre 1 milyon taşıma kapasitesi ve 364 bin $\mathrm{m}^{2}$ lojistik alan kazandıracağ 1 öngörülmektedir. Demiryolu lojistik merkezi ile yükleme boşaltma, stoklama, gümrükleme faaliyetleri gerçekleştirilecek olup, kısa sürede Mersin Limanı'na ulaşım hedeflenmektedir (www.ktso.org.tr- a).

Karaman Mersin Limanı'na 250 km mesafede olup bu coğrafi yakınlık ihracat için önemli avantajlar sağlamaktadır. Karaman'da dış ticaret dengesi sürekli fazla vermektedir. Karaman'dan 2018 y1lı içerisinde toplam 152 ülkeye 303 Milyon Dolar ihracat gerçekleştirildiği görülmektedir. Karaman'da 2018 yılında bisküvi, bulgur ve makarna gibi gıda ürünleri ihracat miktarı 206 Milyon dolar olup bu ürün grubunda gerçekleştirilen tüm ihracat tutarındaki oranı $\% 68$ olarak gerçekleştiği ifade edilmektedir. Çikolata ve çikolatalı ürünler ihracatı, toplam ihracatın \% 15 'ini oluşturarak 45 Milyon dolar ile 2. sırada yer almaktadır. Karaman'dan 152 ülkeye ihracat gerçekleştirilmekte olup ihracat yapılan ülkelere bakıldığında \% 43 gibi büyük bir oranı Irak ilk sırada yer alırken Suriye, Yemen, Libya ve Suudi Arabistan diğer ihracat yapılan ülkeleri oluşturmaktadır. İhracatı yapılan gıda ürünleri, düşük teknoloji yoğunluklu ürün grubu olarak sınıflandırılmaktadır ve bu durum emek yoğun ihracat olduğunu da göstermektedir. Karaman'da işsizlik oranının çok düşük olmasının nedenlerinin başında bu durum gelmektedir (Mevka, 2019: 5-6).

\section{Lojistik Firmalarıyla Yapılan Görüşmeler}

\section{X1 Firması:}

1995 yılında faaliyetine başlayan firma bisküvi, kek, çikolata ve şekerleme üretimi yapmaktadır. Firma yetkilileriyle yapılan görüşmeler neticesinde 110. bin $\mathrm{m}^{21}$ nin üstünde kapalı alanıyla faaliyet gösteren firmanın yurtiçi satışları yanında 90 üzeri ülkeye de ihracat gerçekleştirdiği 
ifade edilmektedir. Karaman'da en çok ihracat yapan firmalardan biri olduğu, 2013-2014 yıllarında Türkiye'nin ilk 500 büyük firması arasına girdiği ifade edilmektedir. Aynı yıllarda Türkiye'de en çok ihracat yapan 1000 firma araştırmasında ilk 200 içinde yer aldığı da firma yetkililerince ifade edilen bir diğer konudur. Kuruluşundan bu yana kaliteye önem verdiklerini iade eden firma, TSE+TSEK, TS-EN+ISO 9001, ISO22000 gibi kalite belgelerine de sahip olduğunu belirtmiştir. Kuruluş döneminde 50'nin altında olan işçi sayısını bugün 1500'e ulaştırdıkları ve ilde istihdama oldukça büyük oranda katkı sağladıkları beyan edilmektedir. Firmanın çalışan profiline bakıldığında;

Tablo 4: X1 Firması Çalışan Profili

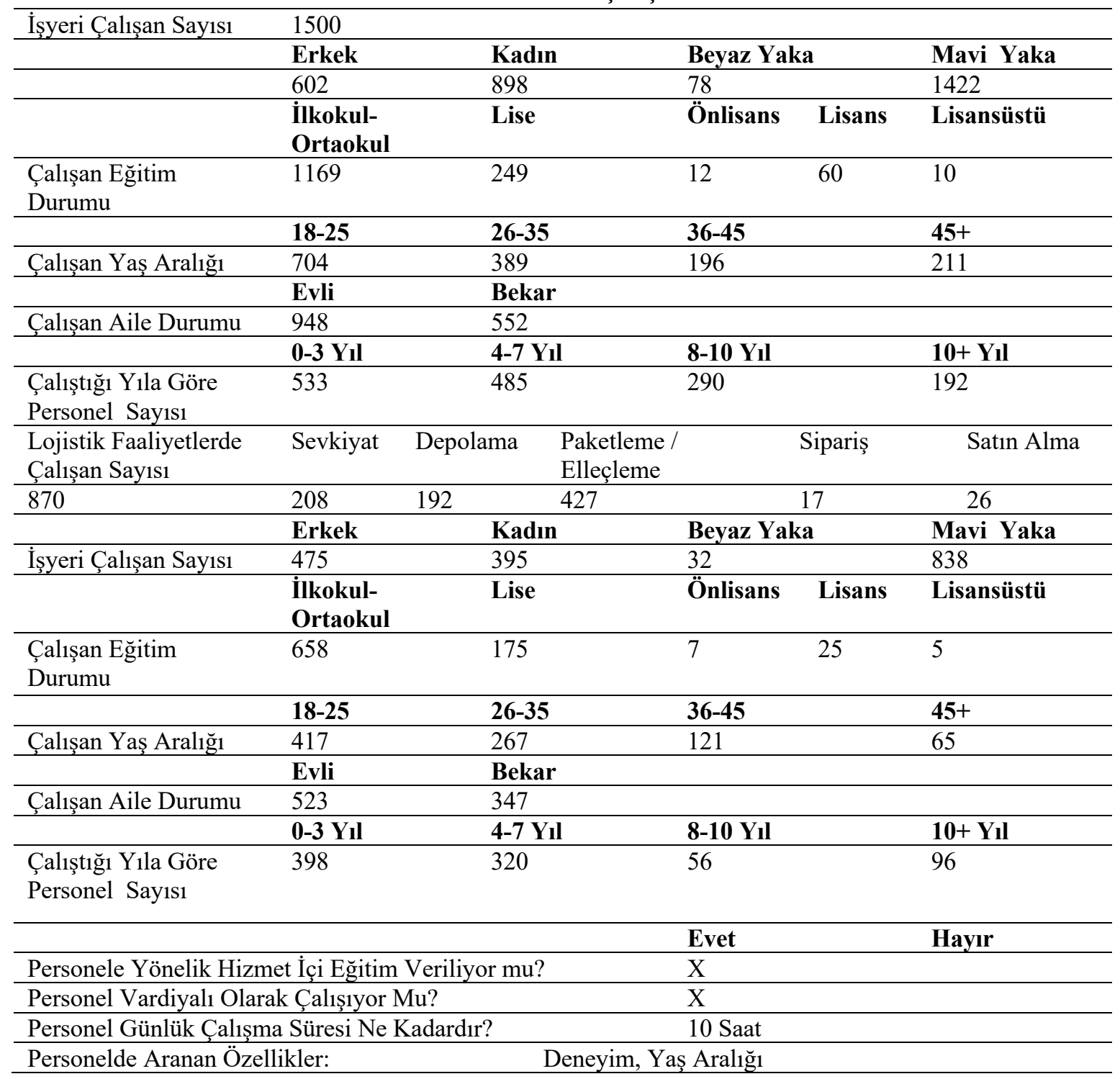

Firmanın gıda imalatı hacmiyle doğru orantılı olarak çok sayıda çalışana sahip olduğu görülmektedir. Firma görüşmesi sonucu elde edilen veriler doğrultusunda mavi ve beyaz yaka olarak profesyonelleşmiş kadroya sahip firmada çalışanların çoğunun işçi kadrosunda olduğu yaklaşık \%5 ' lik kısmının beyaz yaka olduğu, beyaz yaka çalışanlar lisans ve lisansüstü eğitim durumuna sahip olduğu belirtilmektedir. Firmada lojistik faaliyetler departmanlarında 870 kişi çalışmakta olup çalışanların \%78 lük kısmının 35 yaş altı çalışanlardan oluştuğu ifade edilmekte ve bu durumun firmaya yeniliğe açık, eğitilebilir ve dinamik bir çalışan yapısı oluşturduğu ifade edilmektedir. İlkokul- ortaokul seviyesinde eğitim almış kişiler \%75'lik gibi büyük bir kısmı oluşturmakta yine 
firmada çalışanların yüksek kısmının 3 yıldan daha az çalışanlar olduğu görülmektedir. Bu özellikteki çalışanların çoğunun paketleme ve depolama gibi ihtisaslaştırma gerektirmeyen alanlar istihdam edildiği ifade edilmektedir. Kadın çalışanın fazla olduğu firmada, kadın çalışanlar yoğunluklu olarak paketleme ve üretim bantlarında çalıştı̆̆ [belirtilmekte lojistik faaliyetlerde ise ağırlıklı olarak erkek çalışan tercih edilmektedir. Lojistik faaliyetlerde çalışanların \%60 oranla evli oldukları görülmektedir. Firmada günlük çalışma süresi 10 saat olup mavi yaka için vardiyalı çalışma bulunmaktadır. Firma personel seçiminde deneyime önem verdiğini, eğitime açık genç çalışanlara öncelik tanıdığını ifade etmektedir.

\section{X2 Firması:}

Bisküvi sektöründe faaliyet etmek üzere 1995 yılında aile şirketi olarak kurulan firma Karaman Organize Sanayi Bölgesinde faaliyet göstermektedir. Firma yetkilileriyle yapılan görüşmeler sonucunda kuruluş aşamasında $5.000 \mathrm{~m}^{2}$ olan kapalı alanın bugün açık ve kapalı alanıyla toplam $20.000 \mathrm{~m}^{2}$ ye ulaştı̆̆ 1 ve günlük 250 ton üretim hacmiyle faaliyet gösterdiği ifade edilmektedir. 500' ü aşkın ürün yelpazesiyle 85 'in üstünde ülkeye ihracat yaptıkları ifade edilmekte olup geniş Ortadoğu pazarına ilave olarak Çin Pazarına da girerek gelişimine devam ettikleri belirtilmektedir. Firma TS-EN+ISO 9001, ISO22000 gibi kalite belgelerinin tümüne sahip olmasının yanında ilde Yetkilendirilmiş Yükümlülük Sertifikası (YYS) alan ilk firma oldukları belirtilmektedir. Firmanın çalışan profiline bakıldığında; 
Tablo 5: X2 Firması Çalışan Profili

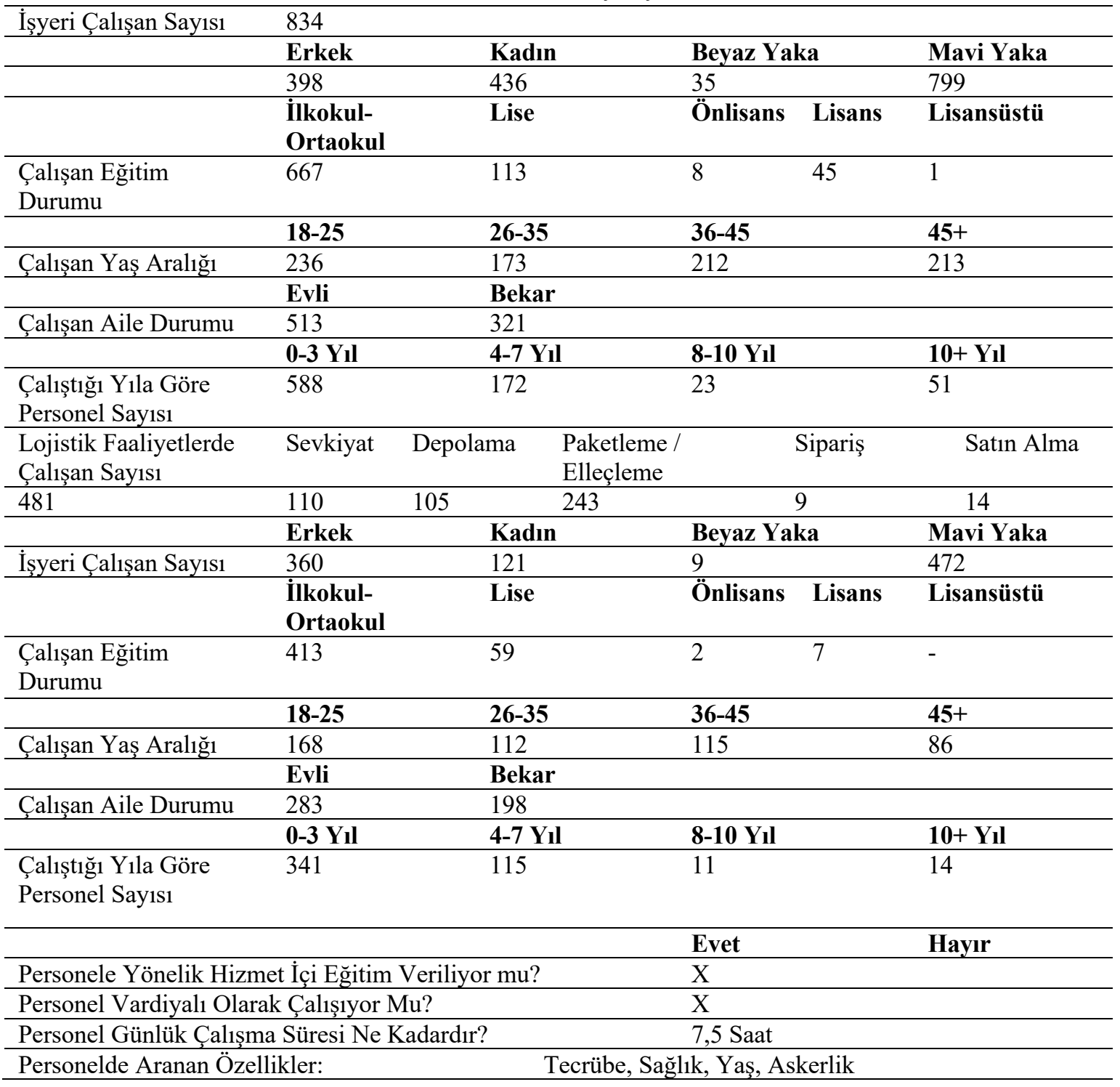

Toplam çalışan sayısı 834 olarak belirtildiği firmada lojistik faaliyetlerde çalışanların sayısının 481 olduğu ve büyük oranda erkek çalışandan oluştuğu ifade edilmektedir. Sevkiyat ve depolama gibi zaman zaman fiziksel gücün gerekli olduğu alanlarda erkek istihdamın yoğun olduğu, paketleme daha yoğun kadın istihdamının olduğu belirtilmektedir. Sorumluluğu ve yetkisi yüksek görevlerde bulunan beyaz yaka çalışanların genellikle 7 yıldan uzun çalışan ve 35 yaş üzeri çalışanlar olduğu belirtilmektedir. Bu durum tecrübe ve istikrarın önemli görevlerde istihdamda belirleyici olduğu sonucunu çıkartmaktadır. Firmada çalışma süresi 3 yıldan az olanlar \%70'lik kısmı oluşturmakta olup genel itibariye 18-25 yaş aralığ çalışanlardan oluştuğu belirtilmektedir. Daha çok vasıfsız işlerde istihdam edilen bu grubun daha çok bekâr oldukları da belirtilmektedir. Olası personel azaltma durumunda bu grup ilk olarak değerlendirilmektedir. 10 yıl ve üzeri çalışanlar genellikle 40 yaş ve üzeri çalışanlar olup kemikleşmiş kadroyu da oluşturduğu ifade edilmektedir. Vardiya sistemiyle çalışan firmanın günlük çalışma süresi 7,5 saattir. Firma işe alım sürecinde tecrübeye önem vermekte olup aynı zamanda askerliği tamamlamış olma, nitelikli işgücü alımında işe göre eğitim almış olma durumuna da önem verdiklerini ifade etmektedirler. 


\section{X3Firması:}

1993 yılında Karaman'da kurulan firma gıda toptancılığı yapmaktadır. Firma yetkilisiyle yapılan görüşmede belirtildiği üzere küçük bir işletme olarak kurulan firmanın 2014 yılında taşındığı yeni mekânı ile $50 \mathrm{~m}^{2}$ 'si ofis olarak diğer kısmı depo olarak kullanılan toplam $600 \mathrm{~m}^{2}$ lik bir işyeri mevcuttur. Gıda toptancılığı sektöründe ilk firmalardan biri olması sebebiyle 26 yıldır ilde tanınırlığı yüksek firmalardan biri olduğu belirtilmektedir. Firma il, ilçe ve köylere gida toptancillk faaliyetlerinin yanı sıra hizmet sektöründe faaliyet gösteren restoran, otel gibi işletmelere de tek kullanımlık ıslak mendil, tuz, şeker gibi paketlenmiş ürün satışı faaliyetlerinde de bulunmaktadır. Firma aynı zamanda yurt çapında büyük bir çay markasının il bayiciliğini de yapmaktadır. Firmanın çalışan profiline bakıldığında;

Tablo 6: X3 Firması Çalışan Profili

\begin{tabular}{|c|c|c|c|c|}
\hline \multirow[t]{2}{*}{$\begin{array}{l}\text { İşyeri Çalışan } \\
\text { Sayısı }\end{array}$} & \multicolumn{4}{|l|}{6} \\
\hline & Erkek & Kadın & Beyaz Yaka & Mavi Yaka \\
\hline \multirow[t]{2}{*}{ Sayıs } & 6 & - & 2 & 4 \\
\hline & İlkokul- Ortaokul & Lise & Önlisans- Lisans & Lisansüstü \\
\hline \multirow{2}{*}{$\begin{array}{l}\text { Çalışan Eğitim } \\
\text { Durumu }\end{array}$} & 1 & 5 & - & - \\
\hline & 18-25 & $26-35$ & $36-45$ & $45+$ \\
\hline \multirow[t]{2}{*}{ Çalışan Yaş Aralığ1 } & 1 & 4 & 1 & - \\
\hline & Evli & Bekar & & \\
\hline \multirow{2}{*}{$\begin{array}{l}\text { Çalışan Aile } \\
\text { Durumu }\end{array}$} & 5 & 1 & & \\
\hline & 0-3 Yll & 4-7 Yll & 8-10 Yll & $10+Y$ Yl \\
\hline \multirow{2}{*}{$\begin{array}{l}\text { Çalıştığı Yıla Göre } \\
\text { Personel Sayısı }\end{array}$} & 3 & 2 & 1 & - \\
\hline & & & Evet & Hayır \\
\hline \multicolumn{3}{|c|}{ Personele Yönelik Hizmet İçi Eğitim Veriliyor mu? } & $\mathrm{X}$ & \\
\hline \multicolumn{3}{|c|}{ Personel Vardiyalı Olarak Çalışıyor Mu? } & & $\mathrm{X}$ \\
\hline \multicolumn{3}{|c|}{ Personel Günlük Çalışma Süresi Ne Kadardır? } & 8-10 Saat & \\
\hline \multicolumn{3}{|c|}{ Personelde Aranan Özellikler: } & \multicolumn{2}{|c|}{$\begin{array}{l}\text { Diksiyonu düzgün kendini ifade } \\
\text { edebilen, çalışma ortamına uyumlu, } \\
\text { askerliğini yapmış, eğitimli, fiziki } \\
\text { yeterliliğe sahip olması. }\end{array}$} \\
\hline
\end{tabular}

Firma kapasitesi gereği 6 çalışan ile faaliyetine devam etmektedir. Firmanın aile şirketi olması nedeniyle firma yöneticiliğinin babadan oğula geçtiği belirtilmektedir. Firma yetkilisi ile yapılan görüşme neticesinde firma sahibi/yöneticisi ve firma muhasebecisi dışındaki kişileri mavi yaka olarak tanımlamakta olup diğer çalışanların depolama, paketleme, sevkiyat ve sipariş faaliyetlerinde bulunduğunu belirtmektedir. Firma muhasebecisinin satın alma ve sipariş işlerini de yürütmekte olduğu belirtilmektedir. 2 kişinin depolama bölümünde 2 kişi de pazarlama ve sevkiyat bölümünde çalıştığı ifade edilmektedir. Depolama ve taşıma faaliyetlerinin yoğun olması nedeniyle çalışanların tümü erkektir. Çalışanların çoğu evli, 26-35 yaş aralığında olup çalışma süresi farklılık göstermektedir. Firma sahibi hariç diğer çalışanlar 2-7 yıl arasında çalışanlar olduğu belirtilmektedir.

\section{X4Firması:}

Karaman Organize Sanayi Bölgesinde bakliyat üzerine faaliyet gösteren firma 1935 yılında kurulan bir aile firmasıdır. Firma yetkilisi ile yapılan görüşmede kuruluş yıllarında daha geleneksel yöntemlerle yapılan imalat 90'lı yılların başında firmanın şirketleşmesiyle birlikte modern işletme tarzına geçildiği belirtilmektedir. Firmanın 3 büyük üretim merkezi, günlük 250 ton üretim kapasitesi ile 38 bayi ve bölge müdürlüğü ile Avrupa Birliği ülkeleri yanında Japonya, Çin, Avustralya gibi 51 
farklı ülkeye kendi markası ile ihracat yaptığı belirtilmektedir. Türkiye'de sektöründe lider ve tanınırlığı yüksek gıda firmalarındandır. Doğal ve sağlıklı bakliyat felsefesi doğrultusunda ISO 9001: 2015 Kalite Yönetim Sistem Belgesi, ISO 22000 Gıda Güvenliği Yönetim Belgesi ve BRC Food Belgesi gibi birçok kalite belgesine sahip oldukları belirtilmektedir. Firma mamullerinin ayrıca HELAL ve KOSHER belgelerine sahip olduğu belirtilmektedir. Sektör profesyonelleri arasında yer alan firma birçok panel, proje ve organizasyonun da öncülerindendir. Firmanın çalışan profiline bakıldığında;

Tablo 7: X4 Firması Çalışan Profili

\begin{tabular}{|c|c|c|c|c|}
\hline \multirow[t]{2}{*}{ İşyeri Çalışan Sayısı } & \multicolumn{4}{|l|}{353} \\
\hline & Erkek & Kadın & Beyaz Yaka & Mavi Yaka \\
\hline & 269 & 84 & 88 & 265 \\
\hline & $\begin{array}{l}\text { İlkokul- } \\
\text { Ortaokul }\end{array}$ & Lise & $\begin{array}{l}\text { Önlisan Lisans } \\
\text { s }\end{array}$ & Lisansüstü \\
\hline \multirow[t]{2}{*}{ Çalışan Eğitim Durumu } & 148 & 135 & 56 & 5 \\
\hline & $18-25$ & $26-35$ & $36-45$ & $45+$ \\
\hline \multirow[t]{2}{*}{ Çalışan Yaş Aralığ } & 30 & 137 & 136 & 50 \\
\hline & Evli & Bekar & & \\
\hline \multirow{2}{*}{ Çalışan Aile Durumu } & 268 & 85 & & \\
\hline & 0-3 Yll & 4-7 Yll & 8-10 Yll & $10+Y_{l}$ \\
\hline $\begin{array}{l}\text { Çalıştığı Yıla Göre } \\
\text { Personel Sayısı }\end{array}$ & 142 & 111 & 38 & 62 \\
\hline $\begin{array}{l}\text { Lojistik Faaliyetlerde } \\
\text { Çalışan Sayısı }\end{array}$ & Sevkiyat & $\begin{array}{ll}\text { Depolama } & \begin{array}{l}\text { Paketleme / } \\
\text { Elleçleme }\end{array}\end{array}$ & Sipariş & Satın Alma \\
\hline \multirow[t]{2}{*}{208} & 59 & 62 & 4 & 6 \\
\hline & Erkek & Kadın & Beyaz Yaka & Mavi Yaka \\
\hline \multirow[t]{2}{*}{ İşyeri Çalışan Sayısı } & 163 & 45 & 22 & 186 \\
\hline & $\begin{array}{l}\text { İlkokul- } \\
\text { Ortaokul }\end{array}$ & Lise & $\begin{array}{l}\text { Önlisan Lisans } \\
\text { s }\end{array}$ & Lisansüstü \\
\hline \multirow[t]{2}{*}{ Çalışan Eğitim Durumu } & 90 & 79 & 32 & 1 \\
\hline & 18-25 & $26-35$ & $36-45$ & $45+$ \\
\hline \multirow{2}{*}{ Çalışan Yaş Aralığ 1} & 31 & 65 & 91 & 21 \\
\hline & Evli & Bekar & & \\
\hline \multirow[t]{2}{*}{ Çalışan Aile Durumu } & 155 & 53 & & \\
\hline & 0-3 Yll & 4-7 Yll & 8-10 Yll & 10+Yll \\
\hline $\begin{array}{l}\text { Çalıştığı Yıla Göre } \\
\text { Personel Sayısı }\end{array}$ & 81 & 64 & 22 & 41 \\
\hline
\end{tabular}

\begin{tabular}{lll}
\hline & Evet & Hayır \\
\hline Personele Yönelik Hizmet İçi Eğitim Veriliyor mu? & X \\
\hline Personel Vardiyalı Olarak Çalışıyor Mu? & X \\
\hline Personel Günlük Çalışma Süresi Ne Kadardır? & 7,5 Saat \\
\hline Personelde Aranan Özellikler: & Kişisel Yetkinlikler, Tecrübe, Göreve Göre Seçim \\
\hline
\end{tabular}

Tabloda görüldüğü üzere firma çalışan sayısı 353 iken bu sayının 208 kişisi lojistik faaliyetlerde istihdam edildiği belirtilmektedir. Gerek üretim bölümünde gerekse lojistik faaliyetlerde erkek yoğun çalışandan oluşmaktadır. Paketleme/Elleçleme bölümünde kadın yoğun ve üretim bölümü beyaz yaka çalışanlarda kadın istihdam yoğun olduğu belirtilmektedir. Lojistik faaliyetlerde çalışanların yaş ortalamasına bakıldığında; fabrika genelinde 18-25 yaş aralığında çalışan kesimin büyük kısmının lojistik faaliyetlerde çalıştıııldığı, özellikle 3 yıldan az tecrübeye sahip çalışanların vasıfsız lojistik faaliyetlerde istihdam edildiği belirtilmektedir. Çalışan yeteneklerine göre ve tecrübe edinme durumuna göre üretim kısmına ya da daha çok nitelik 
gerektiren satın alma, depolama gibi diğer lojistik faaliyetlere yönlendirildikleri belirtilmektedir. Çalışan yönetici iletişimin güçlü olduğu belirtilen firmada istikrara önem verildiği ve yeni işe başlayanların gözlem süreci sonunda yetenekleri, eğitimleri gibi kriterlere göre görevlendirildikleri ifade edilmektedir. Lojistik faaliyetlerine ait çalışan beyaz yakaların ve depo, sevkiyat ve paketleme servis şeflerinin öğrenim durumlarının ön lisans ve lisans seviyesinde olduğu belirtilmektedir. Çalışanların büyük oranda evli olduğu ve işyerine bağlılıkta işyeri açısından evli olmanın avantaj sağladığı belirtilmektedir. Bu durum evli kişilerin kolaylıkla işten çıkmayı göze alamayacakları gerçeği şeklinde de yorumlanabilmektedir. Firma beyaz yaka ve sorumlu/şef/ amir kısmında çalışanları 10 yıl ve üstü çalışanlar olup yaklaşık lojistik çalışanları oranının yaklaşık \%20 si'ni oluşturmaktadır. Firma uzmanlaşmış kadroda personel devir hızını en aza indirmek istediklerini ifade etmekte olup üretim ve lojistik hataları en aza indirmede bu oranın önemini vurgulamaktadırlar.

\section{X5 Firması:}

1996 y1lında karamanda kurulan firma, bisküvi, çikolata, kek gibi çikolatalı ürünler ve unlu gıda ürünleri üretmektedir. $95.000 \mathrm{~m}^{2}$ 'si kapalı alan olmak üzere toplam, $135.000 \mathrm{~m}^{2}$ lik alanda ileri teknolojiye sahip tesislerinde üretimine devam etmektedir. Sektöründe yenilikçi yönü ile birçok ilki başaran firmada 350'nin üstünde ürün çeşidi ile y1llık yaklaşık 115.000 ton üretim gerçekleştiğini ifade etmektedirler. Kaliteli ürün ve rekabetçi bakış açısıyla her geçen gün kendilerini geliştirdiklerini ifade eden firma 100 'ün üzerinde ülkeye de ihracat gerçekleştirdiklerini beyan etmektedirler. Son 20 yılda hızla büyüyerek Türkiye'nin ilk 500 büyük firmasından biri haline gelen firmada markalaşma ve kurumsallaşma konusunda ildeki öncülerden biri olduklarını belirtmektedirler. Firmanın çalışan profiline bakıldığında;

Tablo 8: X5 Firması Çalışan Profili (2018)

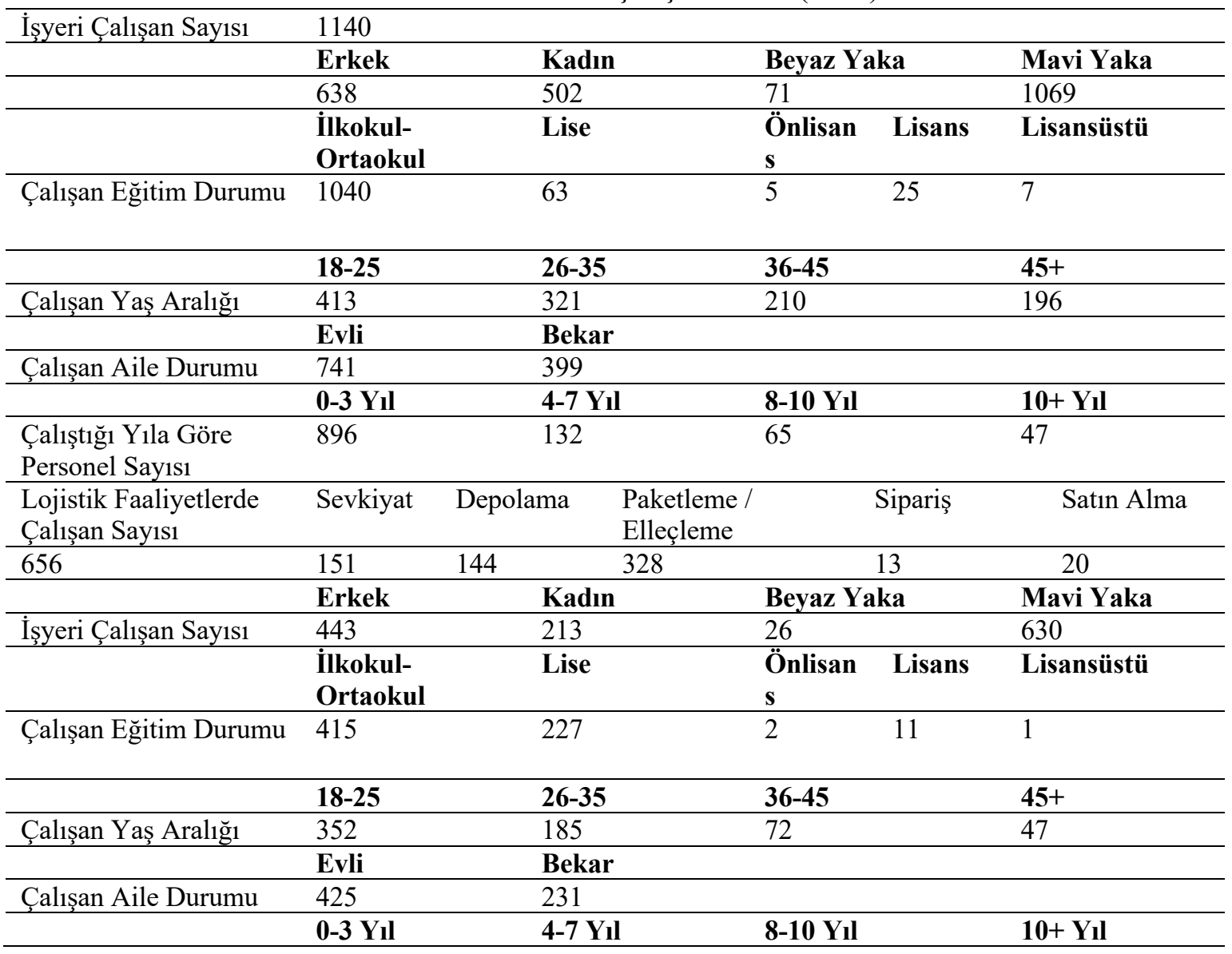




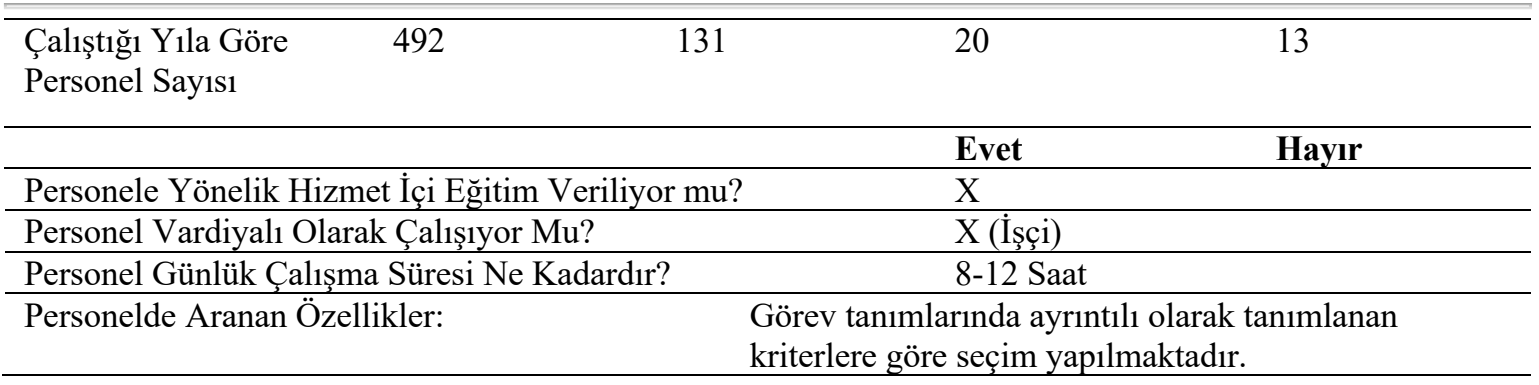

Tablo 9: X5 Firması Çalışan Profili (2019)

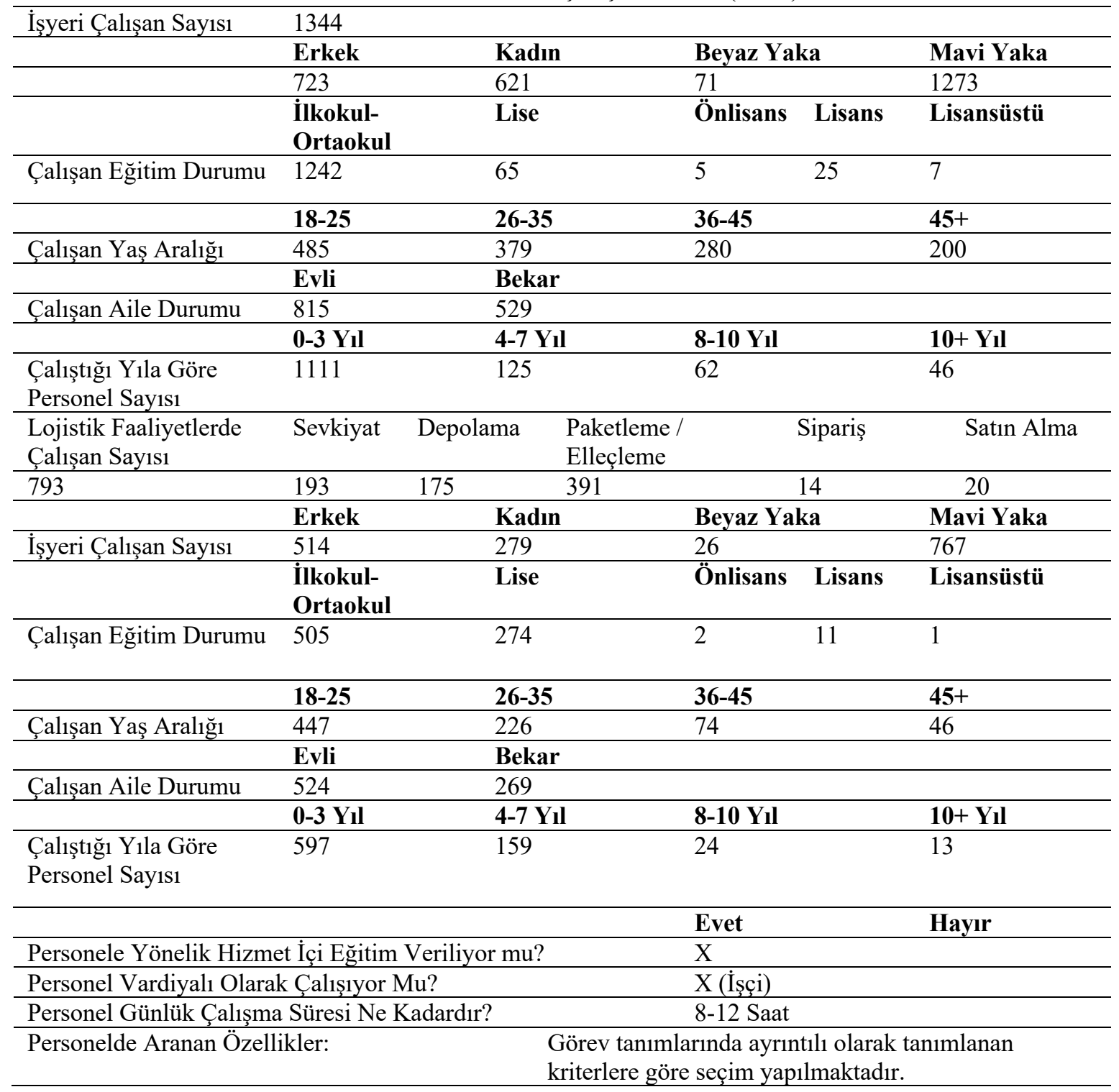

Tablo 8 ve Tablo 9'da firmanın 2018 ve 2019 yılları işgücü profili görülmektedir. Firma yetkilisi ile yapılan görüşme sonucunda oluşturulan tabloya göre; iki yıl arasında işgücü profilinde hemen hemen aynı özellikler görülmekle birlikte çalıșan sayısında artıș görülmektedir. Bu durum yurtiçi ve yurt dıșı talebe bağlı olarak üretim hacminin artmasıyla ilișkili olduğu belirtilmektedir. Beyaz yaka sayısı aynı kalırken işçi kadrosu sayısı artmıştır. Üretim arttıkça nitelik, eğitim gibi özelliklerden bağımsız çabuk temin edilebilen 18-25 yaş arası vasıfsız işçiler istihdam edilerek eksik 
işgücü tamamlanmaktadır. Lojistik faaliyetlerden depolama ve paketleme gibi işlerde çalıştırılarak asgari ücret ödendiği belirtilmiştir. İşçi açığını kapatmak için diğer bir yöntem olarak Doğu kökenli işçi çalıştırıldığı, barınma ihtiyacı firmaca karşılanarak genellikle gece vardiyasında çalıştırıldığı belirtilmektedir. Firmanın her iki yıl içerisinde gerek genel işgücü yapısı gerekse lojistik faaliyetlerde çalışan yapısı benzer özellikler taşımaktadır. Lojistik faaliyetlerde çalışanların büyük oranda erkek çalışan olduğu ve \% 50 den fazlasının 18-25 yaş aralığında olduğu görülmektedir. İlin genel olarak genç nüfusa sahip olması ve ilk kez çalışan kesimin bu yaş aralığında olması oranın artmasına sebep olmaktadır. Bu yaş aralığının dinamik ve yeniliğe açık olması, eğitilebilir oluşu tercih nedenleri arasında sayılmaktadır. Bir diğer tercih nedeni ise asgari ücretle çalıştırılıyor olmasıyla işgücü maliyetini düşürücü etkisi olarak sayılabilmektedir. Lojistik faaliyetlerde çalışanların büyük kısmının ilkokul-ortaokul mezunu olduğu ifade edilmekte olup eğitim durumu yükseldikçe daha vasıflı işlerde çalıştırıldığı ve daha fazla yetki verildiği ifade edilmektedir. Firma çalışanlarının büyük kısmı evlidir ve 0-3 yıl arası çalışmaktadır. 3 yıl altı çalışanlar üretim düşüşüne bağlı daralmaya gidildiğinde işten çıkartılan ilk kesimi oluşturmaktadır. Aylık 100 kişsinin girip çıktığı firmada vasıfsız işçi personel devir hızı fazladır. Usta, şef, amir ve beyaz yakaların daha istikrarlı çalıştı̆̆ 1 ve daha farklı ücret politikasıyla değerlendirildikleri ifade edilmektedir. İşe hakimiyet ve verimlilik gerektiren bu görevler için 35 yaş üzeri ve 7 yıldan fazla çalışanların olduğu ifade edilmektedir. Firma iş hacminin daraldığı dönemlerde işten çıkartma yapmadan önce çalışanların taleplerine göre ücretsiz izin sistemi uygulamaktadır. Özellikle kadın çalışanların bu dönemde ücretsiz izine ayrıldıkları ifade edilmektedir. Temmuz-Eylül dönemi ve Şubat-Mart dönemi üretimin yavaşladığı dönem olup işçi sayısının genellikle bu dönem azaltıldığı belirtilmektedir. Üretim faaliyetlerinde de lojistik faaliyetlerde de vardiya sistemi bulunmakta olup mavi yakanın iş yoğun dönemlerde günlük 8 saat çalışma ile 3 vardiya, işin daha durgun olduğu dönemlerde 12 saatle 2 vardiya olarak çalıştığı ifade edilmektedir. Kadınların genellikle 8 saatlik vardiyalarla çalıştırıldığ 1 , 18 yaş altındaki çalışanlar, hamileler ve gece çalışmak istemeyen kadın çalışanların gece vardiyasında çalıştırılmadıkları ifade edilmiştir. Kalifiye elemanların dışındaki çalışanların genellikle asgari ücretle çalıştırıldıkları belirtilmektedir. Firma çalışan seçiminde nitelikli pozisyonlar için tecrübe ve eğitime önem verirken, vasıfsız işler için genç ve erkek çalışanları tercih etmektedir.

\section{X6 Firması:}

Firma 1997 yılında kurulmuş olup geri dönüşüm firması olarak faaliyet göstermektedir. Organize Sanayi Bölgesinde faaliyet gösteren firma, ilin tek lisanslı geri dönüşüm firmasıdır. Firma yetkililerince yapılan görüşme sonucunda, firmanın fabrikalardan ve şehir merkezinde bulunan atık toplama noktalarından günlük ortalama 15 ton geri dönüşüme konu atık topladıkları ifade edilmektedir. Şehir merkezi atık toplama noktalarından bedelsiz temin edilen atıklar fabrikalardan ve büyük tesislerden bedel karşılığı satın alma yoluyla temin edildiği ifade edilmektedir. 17 adet atık toplama arabasına sahip oldukları, toplanan atıkların tesis içinde bant üzeri akışla kâğıt, metal, cam, plastik gibi türlerine göre tasniflendiği belirtilmektedir. Açık ve kapalı alan toplamı $120.000 \mathrm{~m}^{2}$ olan firmanın, kapasite bakımından Türkiye çapında geri dönüşüm firmaları içinde ilk 5 firma arasında oldukları ifade edilmektedir.

Firma lojistik tanımlamaya göre ters lojistik firması olup tüm lojistik faaliyetleri de içermektedir. Firmanın çalışan profiline bakıldığında; 
Tablo 10: X6 Firması Çalışan Profili

\begin{tabular}{|c|c|c|c|c|c|}
\hline İsyeri Calıșan Sayısı & 72 & & & & \\
\hline & Erkek & Kadın & Beyaz Yak & & Mavi Yaka \\
\hline & 50 & 22 & 8 & & 64 \\
\hline & $\begin{array}{l}\text { İlkokul- } \\
\text { Ortaokul }\end{array}$ & Lise & Önlisans & Lisans & Lisansüstü \\
\hline $\begin{array}{l}\text { Çalışan Eğitim } \\
\text { Durumu }\end{array}$ & 18 & 46 & 7 & 1 & \\
\hline
\end{tabular}

\begin{tabular}{|c|c|c|c|c|}
\hline & 18-25 & 26-35 & 36-45 & $45+$ \\
\hline \multirow[t]{2}{*}{ Çalışan Yaş Aralığı } & 3 & 19 & 42 & 8 \\
\hline & Evli & Bekar & & \\
\hline \multirow[t]{2}{*}{ Çalışan Aile Durumu } & 68 & 4 & & \\
\hline & 0-3 Yil & 4-7 Yil & 8-10 Yil & 10+ Yil \\
\hline \multirow[t]{2}{*}{$\begin{array}{l}\text { Çalıştığı Ylla Göre } \\
\text { Personel Sayıs1 }\end{array}$} & 3 & 9 & 49 & 11 \\
\hline & & & Evet & Hayır \\
\hline \multicolumn{3}{|c|}{ Personele Yönelik Hizmet İçi Eğitim Veriliyor mu? } & $\mathrm{X}$ & \\
\hline \multicolumn{3}{|c|}{ Personel Vardiyalı Olarak Çalışıyor Mu? } & X (İşçi) & \\
\hline \multicolumn{3}{|c|}{ Personel Günlük Çalışma Süresi Ne Kadardır? } & 8 Saat & \\
\hline \multicolumn{3}{|c|}{ Personelde Aranan Özellikler: } & $\begin{array}{l}\text { irtlarına u } \\
\text { sabilecek }\end{array}$ & ak, tecrübeli ve \\
\hline
\end{tabular}

Firmada toplam 72 çalışan bulunmakta olup 22 kadın çalışanı mevcuttur. Firma yetkilileri ile yapılan görüşme sonucunda kadın çalışanların sadece ayrıştırma bantında çalıştıkları ve atık malzemeleri türlerine göre ayrıştırdıkları belirtilmektedir. Karaman'ın sıfır atık projesinde pilot bölge olması nedeniyle ve ilin tek geri dönüşüm firması olması nedeniyle işin yoğun olduğu ifade edilmektedir. Günlük 8 saat çalışma ile 3 vardiya bulunmaktadır. Kadın çalışanlar açısından pozitif cinsiyet ayrımı yapıldığı ifade edilerek, vardiyalı olarak çalıştırılmadıkları, Pazar günleri kesinlikle çalışmadıkları ve dinlenme saatlerinin erkek çalışanlara oranla daha uzun olduğu ve kamerasız alanda çalıştıkları belirtilmektedir. 30 yaş üstü lise mezunu ve 7 yıldan uzun çalışanların daha fazla olduğu firmada istikrara önem verilmektedir. İşin yoğunluğu ve zorluğu, çalışan bulmada güçlük yarattığı için mevcut çalışanlar izin, ücret gibi yönden desteklendiği ifade edilmektedir. Çalışanların tamamına yakınının evli olduğu firmada çalışanın evli olması istikrar açısından avantaj olarak görülmektedir. Çalışanların \%50'sinden fazlası lise mezunudur, bu durum aynı zamanda sosyal sorumluluk bilincinin de etkili olduğu geri dönüşüm firmasında bilinç düzeyini yükseltmekte ve işin daha verimli ve hızlı olmasını sağlamaktadır. Firmada personel devir hızı oldukça düşük olduğu ve bunun firma için istenir bir durum olduğu ifade edilmektedir.

\section{Değerlendirme}

\section{Profilin Ekonomik Yönleriyle Değerlendirilmesi}

Karaman İli lojistik faaliyetler çalışmasının geneline bakıldığında ilin çalışabilir genç nüfusu nedeni ile firmalar açısından işgücü temininde zorluk çekilmediği söylenebilmektedir. Özellikle 1825 yaş aralığında vasıfsız işçi yoğunluğu fazla olmakta, bu çalışanlar asgari ücret ile istihdam edildiğinden firma açısından ucuz ve bol işgücü olarak ifade edilebilmektedir. Vardiyalı olarak çalıştırılabilen işgücü üretimin aralıksız ve verimli çalışmasını da sağlamaktadır. Üretim daraldığı dönemde işten çıkartma ve iş yoğunluğu döneminde kolayca işgücünün temini de firma açısından risksiz bir durum olarak gözlemlenmektedir. Sendikasız çalışmanın yoğun olduğu Organize Sanayi Bölgesi, Karaman firmaları açısından yasal ve ekonomik olarak da kolaylık sağladığı belirtilebilmektedir. İlde çok sayıda benzer yapıda lojistik faaliyette bulunan firmanın oluşu ( bisküvi 
fabrikaları, bulgur fabrikaları vs.) personel devir hızını arttırmakta çalışanlar açısından firmalar arasında sirkülasyona neden olabilmektedir.

\section{Profilin Sosyolojik Yönleriyle Değerlendirilmesi}

Karaman ilinde yapılan lojistik faaliyetinde çalışan firmalarla yapılan çalıșma sonucunda çalışanların sosyal durumları incelendiğinde erkek yoğun çalışmanın olduğu söylenebilmektedir. Vardiyalı çalışmada ve fiziksel gücün gerektiği durumlarda avantaj sağlayan bu cinsiyetçi seçim kadın çalışanların gece vardiyasına sıcak bakmaması, genellikle evli ve çocuklu olmaları nedeniyle izin ve rapor durumlarının sıklı̆̆ı firma açısından dezavantaj olarak algılanmaktadır. Eğitim olarak ilkokul ortaokul mezununun fazla olduğu profilde işyerinden maddi ve manevi beklenti de az olmakta, işçinin sadece geçimi sağlamaya odaklandığı söylenebilmektedir. Kariyer, manevi tatmin ya da saygınlık gibi beklentilere girmemektedir. Çalışanların çoğunluğun evli olduğu göz önüne alındığında kolaylıkla işten çıkmayı göze alamayan çalışan tipinin de yaygın olduğu söylenebilmektedir. İlin küçük ve kapalı bir il olması eğitim düzeyinin işçi profilinde düşük olması, yükseköğrenimini düşünmeyen kesimin askerlik yaşının erken oluşu ve muhafazakar il gereği askerlik sonrası erken yaş evliliklerinin yoğunluğu 18-25 yaş arası ve deneyimi az çalışanlarında evlilik oranlarını yükseltmektedir.

İl merkezi yanında köylerden ve hatta çevre illerin ilçelerinden (Mut, Silifke vb) de çalışan temini sağlanmakta olup şehire ciddi anlamda göçe sebebiyet vermektedir. İl merkezindeki bu çalışma imkanı kırdan kente göçü arttırmaktadır.

\section{Profilin Diğer Yönleriyle Değerlendirilmesi}

Karaman ili Lojistik faaliyetleri bünyesinde bulunduran firmalar ile ilgili yapılan çalışmalarda firmaların işgücü profili bakımından büyük oranda benzerlik gösterdiği ifade edilebilmektedir. Şehirde istihdamın genç ve tecrübesiz kişilere de yönelik olması, yükseköğrenimin gerekli olmadığ 1 vasıfsız işlerde istihdam yaratmanın kolay oluşu ve işsizlik oranının düşük olması özellikle orta öğretimini tamamlayıp eğitimine devam etmeyen kişiler için firsat yaratmaktadır. Bu durum işsizlik açısından olumlu bir durumken kişisel gelişime ket vuran, kişileri kısa yoldan para kazanmaya iten olumsuz bir durum olarak da ifade edilebilmektedir.

İlde köyden kente göçün yanında diğer illerden ve Doğu illerinden de çalışmak için göç kabul ediyor olması nüfusun heterojen bir yapıya dönüşmesine de zemin hazırlamaktadır. Asgari geçim standardında ücret alan çalışan kesimin yoğunluğu şehrinde orta segment üzerine gelişimini sağlamaktadır.

Karaman'da üretim üzerine lojistik faaliyetlerin yoğun olması ve Akdeniz Bölgesi ile İç Anadolu Bölgesi arasında geçiş noktası olması lojistik sektörünün ve lojistik sektörü çalışanlarının önemini her daim koruyacağı sinyallerini de vermektedir.

Genel olarak yapılan çalışma sonucunda aşağıdaki verilere ulaşıldığı söylenebilmektedir. 


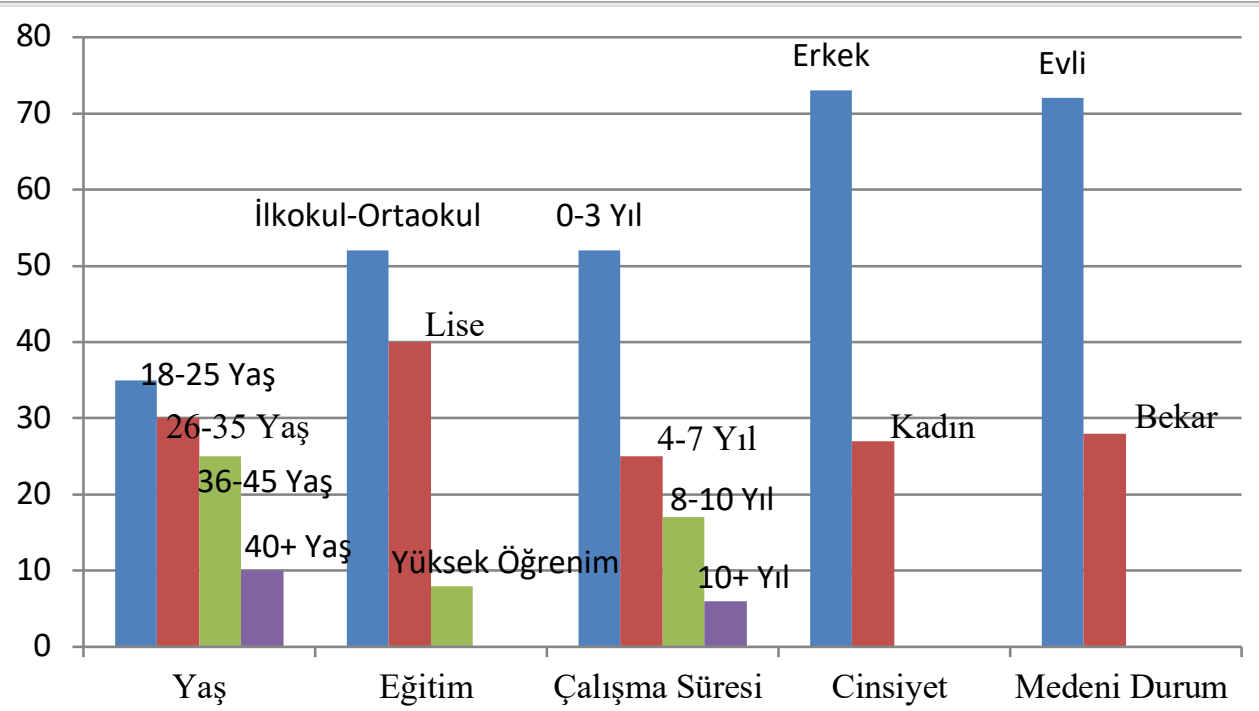

Şekil 5: Karaman İli Lojistik Çalışanları İşgücü Profili

Şekil 5 'de de görüldüğü üzere $18-25$ yaş aralığg \%35 oranla ilk sırada yer alırken, 26-35 yaş aralığ $1 \% 30,35-45$ yaş aralığ1 \%25 olarak tespit edilmiştir. Yaş arttıkça doğru orantılı olarak tecrübede artmaktadır. İşçi alımlarında vasıfsız görevlere daha genç ve dinamik çalışanlar tercih edilirken, sorumluluğun ve insiyatifin arttığı görevlere daha tecrübeli kişiler tercih edilmektedir. İlin genel genç nüfus profilinin işgücü profiline de yansıdığı ifade edilebilmektedir. Çalışanların \%52'lik kısmı 3 yıldan daha az süreyle işyerinde çalışan kişilerden oluşmaktadır. 10 yıl üzeri çalışanlar firmada yoğunlukla önemli görevlere sahip kişilerden oluşmaktadır ve \%6 'lık gibi az kişiyi temsil etmektedir. Personel devir hızının fazla olması benzer yapıda firmaların çokluğu ve işsizlik oranının az olması nedeniyle kolay işten ayrılma ve tekrar başka firmada işe başlamayı kolaylaştırmaktadır. $\mathrm{Bu}$ durum firma istikrarını ve çalışanın aynı işyerinde deneyim kazanmasını engelleyici bir faktör olarak karşımıza çıkmaktadır. Lojistik sektörü çalışanlarının \%73 'lük kısmını erkek çalışanlar oluşturmaktadır. Fiziksel güç, erkeklerin vardiyalı sistemde daha rahat çalışılabilir olması, kadın çalışanların evlilik ve doğum gibi sebeplerle işe devam edememeleri ve ilin daha kapalı yapısı erkek çalışanları daha tercih edilebilir kılmaktadır. Çalışanların \%72'si evlidir. Bu durum erkek çalışanları iş yerine daha bağımlı hale getirirken kadın çalışanlar için dezavantajlı bir durum olarak görülmektedir. Lojistik sektörü çalışanlarının eğitim durumlarına bakıldığında \%52 ile ilkokulortaokul mezunlarının ilk sırada yer aldığ,$\% 40$ 'lık oran ile lise mezunlarının ikinci sırada, \%8'lik oranla yükseköğrenim görmüş olan çalışanların üçüncü sırada olduğu görülmektedir. Yükseköğrenim gören çalışanlar genellikle beyaz yaka çalışanlar olup birim yöneticileri konumundadırlar. Genç nüfus için kolay iş bulunabilir olması yükseköğrenime gerek duymayan, kısa yoldan para kazanmaya odaklanan bir kesimi de ortaya çıkartmaktadır.

\section{Sonuç ve Öneriler}

Kökeni eski çağlara kadar dayansa da lojistik son dönemde yıldızı parlayan bir sektör olarak karşımıza çıkmaktadır. Sektör bünyesinde bulundurduğu sipariş, satın alma, depolama, elleçleme, sevkiyat gibi her bir başlı başına uzmanlık gerektiren faaliyetler bütünü olması yanında üretimin ve tüketimin her aşamasında oluşu nedeniyle önemli bir sektör olarak karşımıza çıkmaktadır. Teknolojik gelişmeler, hızla gelişen ticaret, globalleşen dünya zorlu rekabeti de beraberinde getirmektedir. Rekabet yeteneğinde çalışanların niteliği büyük öneme sahiptir. İşinde yeteli donanıma sahip, piyasa koşullarına hâkim, tecrübeli, gelişime açı nitelikli işgücü hem sektörün gelişiminde hem firma düzeyinde gelişimde etkin rol oynamaktadır. Lojistik faaliyetler bütünleşik 
yapıs1 gereği bilgi, teknoloji, gelişim ve değişimi içine alan bir süreçtir ve bu sektörde çalışanların bu özelliklere uyumu beklenmektedir.

Günümüzde lojistik performansın iyileştirilmesi sadece altyapısal ve teknolojik gelişim olarak algılanmamalı insan gücüne olan yatırım da iyileştirilmelidir. Firma düzeyinde ekonomik hedeflere ulaşmada insan sermayesi dinamik gücü oluşturmaktadır.

Karaman ilinde yapılan lojistik faaliyetlerde çalışan işgücüne yönelik profil çalışmasında firma kapasitesi ve üretim hacminin arttıkça çalışan sayısının da aynı oranda arttığı söylenebilmektedir. Özellikle üretime dayalı lojistik faaliyetlerde bulunan firmalarda mavi yakalı çalışan sayısı daha fazladır. Beyaz yaka çalışanlar, firmada çalışma süresi daha uzun, tecrübeli ve iyi eğitimli çalışanlardan oluşmaktadır. Süreçte söz sahibidirler ve insiyatif kullanabilmektedirler. Maaş olarak mavi yakaya göre daha avantajlı olan bu kesim kişisel ve mesleki gelişime daha açıktır. Oransal olarak mavi yaka çalışanlara göre daha az sayıdadırlar ve yükseköğrenim gören tüm çalışanlar bu gruptadırlar.

Karaman ili lojistik faaliyetlerde çalışan profilinde 18-25 yaş arası, ilkokul-ortaokul mezunu, işyerinde 3 yıldan daha az çalışan evli erkek yoğun profil göze çarpmaktadır. Düşük ücretle çalıştırılabilir ve üretimin azaldığı durumda kolayca gözden çıkartılabilir olması nedeniyle tercih edilen bu çalışanlar işgücü maliyetini düşürmede avantaj olarak görülse de nitelikli işgücüne sahip olma konusunda yetersiz kalmaktadır. Ağırlıklı olarak depolama ve paketleme bölümlerinde vasıfsız işlerde çalıştırılmaktadırlar.

Lojistik sektörü işgücü profili değerlendirilmesi sonucunda Karaman ili için niteliksiz ve tecrübesiz işgücünün varlığından söz edilebilmektedir. Hız, kalite, güven unsurlarını bünyesinde bulunduran bu sektörde zorlu rekabette yer edinebilmek ve maliyet avantajını sağlamak adına iyi yetişmiş, donanımlı ve istikrarlı çalışanlara gerek duyulmaktadır. Bu bağlamda firmalar kendi lojistik ekiplerini kurmaya odaklanmalı, gerekli eğitimle iyi yetişmiş elemanlar istihdam etmeli ve adil ücret politikası ile firmada çalışılan süreyi uzatmalıdır. Kalifiye işgücü sorununun çözümüne yönelik firma politikaları oluşturulmalıdır. Özellikle sektör genel itibariye eğitime önem vermeli teorik eğitim pratik eğitimle desteklenmeli, sektör seçici bir kimle özendirici ve seçkin bir sektör haline gelmelidir. Lojistik hizmet standardını oluşturmaya yönelik çalışmalar için meslek birlikleri ile ortak hareket etmelidirler. Düşük işgücü maliyeti yanında yüksek verimlilik de gözetilmelidir. Firma rekabet gücünü arttırmada ve markalaşmada insan gücünü kullanmalıdır. Bilgi, teknoloji ve insan öznesini bütünleştirmeli, sürekli öğrenme ve gelişim uygulamalarıyla hem çalışanları hem de firmayı geliştirmelilerdir.

İlin gelişmiş sanayisi ve 150 'den fazla ülkeye ihracat yaptığı göz önüne alındığında istikrarlı çalışanların önemi fark edilmelidir. İstikrara bağlı tecrübe ve kurumsal aidiyet sağlanmaya çalışılmalıdır. Aynı çalışanın uzun süreli istihdamı amaçlanmalı ve yetenekleri doğrultusunda görevler verilmeli ve eğitimle desteklenmelidir.

Devlet politikaları da lojistik sektörü çalışanlarını destekler yönde olmalı, sektörde vasıfsız çalışanlarların orta öğrenim seviyesinde lojistik eğitimi almalarına yönelik lojistik bölümü içeren meslek liseleri kurulmalıdır.

\section{Kaynakça}

Adal, Z. (2015). Lojistik sektöründe çalışma ilişkileri, Lojistik Sektöründe İnsan Kaynakları Yönetimi Uygulamaları, Beykoz Lojistik Meslek Yüksekokulu Yayınları 15, Birinci Baskı: 149-256. 
Akar, G.S. \& Çakır, E. (2016). Lojistik sektöründe bütünleştirilmiş bulanık ahp - moora yaklaşımı ile personel seçimi, Yönetim ve Ekonomi Araştırmaları Dergisi - Cilt:14 Sayı:2, 185-199.

Akçay, V. H. (2005). Lojistikte demiryolu taşımacılığının önemi [Yayınlanmış Yüksek Lisans Tezi]. Marmara Üniversitesi Sosyal Bilimler Enstitüsü.

Akdemir, H. Y. (2011). Lojistik sektörü iş gücü profilinin değerlendirilmesi İzmir ili örneği [Yayınlanmış Yüksek Lisans Tezi]. Dokuz Eylül Üniversitesi Sosyal Bilimler Enstitüsü.

Alamdarı, G.T. (2016). The role of logistics in branding [Yayınlanmış Yüksek Lisans Tezi]. Yaşar University, Graduate School of Social Sciences.

Asyal1, E. \& Tuna, O. (2015). Lojistik sektöründe insan kaynakları uygulamaları: kariyer yönetimi üzerine bir çalışma, Lojistik Sektöründe İnsan Kaynakları Yönetimi Uygulamaları, Beykoz Lojistik Meslek Yüksekokulu Yayınları 15, Birinci Baskı: 81-101.

Babacan, M. (2003). Lojistik sektörünün ülkemizdeki gelişimi ve rekabet vizyonu, Ege Akademik Bakış, 3(1). 8-15

Baştaymaz, T. (1998). Gelişmekte olan ülkelerdeki açmaz: işsizlik veya kırsal eksik istihdam, Mercek Dergisi, Mess Yayım.

Bayraktutan Y. \& Özbilgin M. (2015). Lojistik maliyetler ve lojistik performans ölçütleri, Maliye Araştırmaları Dergisi, Yı1:1, Cilt:1, Sayı:2, 95-112.

Bayramoğlu, K. (2014). Lojistik sektörü devlet politikalarl ile desteklenmeli-Nilgün Keleş ile röportaj, Ekovitrin, 136-141.

Bölükbaş, Ö. (2016). Türkiye'de lojistik sektörü ve lojistik köyler [Yayınlanmış Yüksek Lisans Tezi]. Marmara Üniversitesi Sosyal Bilimler Enstitüsü İktisat Anabilim Dalı.

Chopra, S. \& Meindl, P. (2007). Supply chain management, strategy, planning and operation, 3th. Edition, Prentice Hall.

Colombo, M.G. \& Grilli, L. (2005). Founders' human capital and the growth of new technologybased firms: a competence-based view, Research Policy, 34: 795-816.

Çakaloz, B. \& Tuna O. (2013). Lojistik yönetiminde simülasyon temelli eğitim yaklaşımları, Lojistikte Güncel Konular Kavramlar ve Uygulamalar, Beykoz Lojistik Meslek Yüksekokulu Yayınları:6, 2-28.

Çekerol, G.S. \& Kurnaz, N. (2011). Küresel kriz ekseninde lojistik sektörü ve rekabet analizi, Selçuk Üniversitesi Sosyal Bilimler Enstitüsü Dergisi, 25, 50-58.

Çondur F. \& Bölükbaş M. (2014). Türkiye'de işgücü piyasası ve genç işsizlik büyüme ilişkisi üzerine bir inceleme, Amme İdaresi Dergisi, Cilt 47, Say1 2, 77-93.

Daşkan, E.S. (2016). Türkiye’de lojistik sektörünün gelişi ve gelecek öngörüleri, Tartışma Metinleri, Ticaret Üniversitesi.

Demirbilek, A. (2018). Küresel ticarette lojistik performans düzeyi ile havayolu kargo taşımacılığı ilişkisi [Yayınlanmış Yüksek Lisans Tezi]. İstanbul Ticaret Üniversitesi Sosyal Bilimler Enstitüsü.

Erkan, B. (2014). Türkiye'de lojistik sektörü ve rekabet gücü, ASSAM Uluslararası Hakemli Dergisi, Say1:1, 45-66.

Erol, F. (2015). Lojistik köylerin önemi ve intermodal taşımacıllk faaliyetleriyle desteklenmesi: Karaman ilinde bir uygulama [Yayınlanmış Yüksek Lisans Tezi]. Karamanoğlu Mehmetbey Üniversitesi Sosyal Bilimler Enstitüsü. 
Hatch, N. W., \& Dyer, J. H. (2004). Human capital and learning as a source of sustainable competitive advantage, Strategic Management Journal, 25(12), 1155-1178.

https://www.lojistikcilerinsesi.biz/2019/01/09/1ojistik-sektorune-dair-2019-yili-ongoruleri/, Erişim: 10.10.2019

http://www.odd.org.tr/web_2837_1/entitialfocus.aspx?primary_id=1320\&target=categorial1\&type $=33 \&$ detail $=$ single, Erişim: 18.10 .2019

https://piyasarehberi.org/sozluk/isgucu , Erişim: 15.10.2019

https://www.utikad.org.tr/Detay/Sektor-Haberleri/23460/lojistik-performans-endeksi-2018-veturkiye , Erişim: 17.10.2019

https://www.tuik.gov.tr/OncekiHMArama.do , Erişim: 20.10.2019

https://www.iskur.gov.tr/kurumsal-bilgi/raporlar (IPA, 2018), Erişim: 19.10.2019

http://www.karaman.gov.tr/nufus (12.12.2019)

Karaman'ın Sosyo Ekonomik Yapısı 2018 (2018), Karaman Sanayi ve Ticaret Odası (b) https://www.ktso.org.tr/UserFiles/File/2018\%20sosyoekonomikveriler.pdf

Karaman Dış Ticaret Analiz Raporu (2019) Mevlana Kalkınma Ajansı https://www.mevka.org.tr/Yukleme/Uploads/Dsy90oJNh513201920404PM.pdf

Kaya, O. (2013). Atatürk'ten lojistik dersleri, Lojistikte Güncel Konular Kavramlar ve Uygulamalar, Beykoz Lojistik Meslek Yüksekokulu Yayınları: 6, 232.

Keskin, M. H. (2009). Lojistik, tedarik zinciri yönetimi (Geçmişi, Değişimi, Bugünü, Geleceği) Nobel Yayınları, 3. Baskı.

Koban, E. \& Keser, E. H. Y. (2013). Rekabet edebilirlikte Türk lojistik sektörünün istihdam yapısının analizi ve istihdama yönelik devlet destekleri, Çalışma İlişkileri Dergisi, Cilt 4, Sayı 2, 32 43.

Koru, A. T. \& Dinçer, N. N. (2018). Türkiye'de sanayi ve hizmet sektörleri, İktisat ve Toplum Dergisi, Say1: 88.

Oda, S. (2008). Türkiye'de lojistik sektörü ve dış ticaret üzerine etkileri [Yayınlanmış Yüksek Lisans Tezi]. Trakya Üniversitesi Sosyal Bilimleri Enstitüsü.

On Birinci Kalkınma Planı (2019-2023), Temmuz 2019, Türkiye Cumhuriyeti Cumhurbaşkanlığı Strateji ve Bütçe Başkanlığı, (www.sbb.gov.tr) 15.10.2019

Orhan, O.Z. (2014). Dünyada ve Türkiye'de lojistik sektörünün gelişimi, İstanbul Gelişim Üniversitesi Yayınları 04.

Özdener, H.H. (2010). Lojistikte toplam kalite yönetimi [Yayınlanmış Yüksek Lisans Tezi]. Kadir Has Üniversitesi Sosyal Bilimler Enstitüsü.

Rushton, A., Croucher, P. \& Baker, P. (2006). The handbook of logistics and distribution management, 3th, ed. Kogan Page.

Schumacher, J., Gschweidl, M. \& Rieder, M. (2009). Eurodice mobile agents architecture for distributed intelligence, ITS World.

Sektörel Bakış 2019 - Taşımacılık https://home.kpmg/tr/tr/home/gorusler/2019/05/sektorel-bakis2019-tasimacilik.html, Erişim: 15.10.2019 
Şekkeli, Z. H.(2016). Lojistik stratejilerinin rekabet avantajı ve lojistik performansina olan etkileri üzerinde Türkiye ölçeğinde bir araştırma [Yayınlanmış Doktora Tezi] Kahramanmaraş Sütçü İmam Üniversitesi, Sosyal Bilimler Enstitüsü.

Tansel, A. (2012). 2050’ye doğru nüfusbilim ve yönetim: işgücü piyasasına bakış, TÜSİAD Yayınları.

T.C. Kalkınma Bakanlığı, (2013). Onuncu kalkınma planı 2014-2023, 1-199.

Tekin, M. (2013). Lojistik, Eralp Yayınları, 1. Baskı.

Tufan, C. \& Uğurlu, Ö.Y. (2019). Lojistik sektöründe öğrenme kültürü, Bilgi Yönetimi, İnsan Sermayesi ve Örgütsel Etkililik İlişkisi, Adlyaman Üniversitesi Sosyal Bilimler Enstitüsü Dergisi, Y11: 11, Say1: 31

Türkiye Odalar ve Borsalar Birliği (Tobb) (2018), Ekonomik raporu, 75. Genel Kurul (www. tobb.org.tr) 15.10.2019

II.Ulaştırma ve Lojistik Kongreleri-ULUK (2018) Ulaştırma ve lojistik sektör raporu, (http://ulk.ist/kutuphane/) 15.10.2019

Uyanık, Y. (2008). Neoliberal küreselleşme sürecinde işgücü piyasaları, Gazi Üniversitesi İktisadi ve Idari Bilimler Fakültesi Dergisi 10 / 2, 209-224.

Van Hoek, R. \& Harrison, A. (2011) Logistics management and strategy, Financial Times Prentice Hall.

28 Nedenle Karaman'da Yatırım (2018). Karaman sanayi ve Ticaret Odas1 (a), https://www.ktso.org.tr/28nedenlekaramanayaitirim.pdf (12.12.2019) 